\title{
Petrotectonic framework of granitoids and associated granulites at Nagavalli Shear Zone (NSZ), Eastern Ghats Belt: Evidence of a late transpression orogeny
}

\author{
TAmoghna Saha and Subrata KarmakaR* \\ Department of Geological Sciences, Jadavpur University, Kolkata 700 032, India. \\ *Corresponding author. e-mail: subrata.jugeol@gmail.com
}

\begin{abstract}
Megacrystic granitoids associated with migmatitic and metasedimentary gneisses occurring around Nagavalli Shear Zone (NSZ) preserve complex metamorphic and deformation history. Thinly laminated discontinuous banding of quartzofeldspathic layer $\left(\mathrm{S}_{1}\right)$ in the migmatites is the product of first incipient melting during prograde $\mathrm{M}_{1}-\mathrm{D}_{1}$ tectonothermal event. Peak $\mathrm{M}_{2}-\mathrm{D}_{2}$ event is manifested by the development of $\mathrm{S}_{2}$ gneissic foliation in all rocks, which is axial planar to rootless folds on $\mathrm{S}_{1}$. Porphyroblastic garnet mantled by leucosomal melt fraction in granitoids, suggest that the rock suffered peak granulite facies metamorphism along with host migmatitic gneisses. The subsequent $\mathrm{D}_{3}$ event deforms differently the massive granitoids and the migmatitic granulite gneisses. The $\mathrm{D}_{4}$ deformation acted as transpression with broad northwest-southeast compression that develops strong discontinuous regionalscale anastomosing shear zones transecting the earlier gneissosity $\left(\mathrm{S}_{2}\right)$ in the granitoids with prominent sinistral shear sense. It deforms the axial plane of regional folds in migmatites and develops superposed non-plane non-cylindrical folds in outcrop to regional scale. Thus we infer megacrystic granitoids were possibly emplaced in pre- to syn-peak metamorphic event within the host granulites. Granitoids and associated migmatitic gneisses of Late Meso- to Neoproterozoic age suffered subsequent petrotectonic events followed by a sinistral transpression acted along NSZ.
\end{abstract}

\section{Introduction}

Eastern Ghats Belt (EGB), a deeply eroded highgrade terrane is the product of polycyclic granulite metamorphism (Dasgupta and Sengupta 2003; Mukhopadhyay and Basak 2009; Karmakar et al. 2009). Rickers et al. (2001) demonstrated Eastern Ghats Belt as collage of juxtaposed terranes. Recently, Dasgupta et al. (2013) proposed EGB as accreted crustal fragments, which were amalgamated through discrete orogenic cycles during Paleo-Mesoproterozoic, Meso-Neoproterozoic, and Late Neoproterozoic times (Dobmeier and Simmat
2002; Simmat and Raith 2008; Karmakar et al. 2009; Mukhopadhyay and Basak 2009; Bose et al. 2011; Das et al. 2011). This belt had been classified on the basis of petrographic, lithological, metamorphic, geochronologic as well as structural data (Ramakrishnan et al. 1998; Dobmeier and Raith 2003; Chetty 2001). Ramakrishnan et al. (1998) introduced a four-fold longitudinal subdivision, viz., Western Charnockite Zone (WCZ), Western Khondalite Zone (WKZ), Central Migmatite Zone (CMZ), and Eastern Khondalite Zone (EKZ). Based on the $\mathrm{Nd}, \mathrm{Rb}-\mathrm{Sr}$ and $\mathrm{Pb}$ isotopic signatures of ortho- and paragneissic rocks of the entire EGB,

Keywords. Granitoids; tectonothermal events; peak metamorphism; Nagavalli Shear Zone (NSZ); sinistral shear; transpression. 
Rickers et al. (2001) subdivided EGB into four crustal domains (figure 1). Domain 1 broadly coincides with western charnockite zone (WCZ) and is subdivided into $1 \mathrm{~A}$ and $1 \mathrm{~B}$. Domain $1 \mathrm{~A}$, situated at the southern part, is characterized by homogeneous Nd-model ages for paragneisses (2.8-2.6 Ga) and orhthogneisses $(2.5-2.3 \mathrm{Ga})$. In the northern part, Domain 1B is characterized by older crustal protolith (3.9-3.2 Ga of orthogneisses). Domain 2 consists of central migmatite zone (CMZ) and eastern khondalite zone (EKZ) and shows very complex isotopic characters. Metasediments have Nd model age of 2.5-2.1 Ga, while the orthogneisses have a wide Nd-model age spanning 3.2-1.8 Ga. Domain 3 is situated north of Domain 2 and shows fairly homogeneous Nd-model age $(2.2-1.8 \mathrm{Ga}$ for both metasediments and orthogneisses). This domain has more juvenile addition compared to the others. Domain 4 is situated at the extreme northern part with Nd-model age of $3.2 \mathrm{Ga}$ for the orthogneisses and 2.8-2.2 Ga for the metasediments. The essence of the subdivision of EGB is that the protolith history of all the four crustal domains is contrasting. The sources of the sediments deposited on a basement (of unknown age) are the adjoining Archean cratons, while small but variable quantities of juvenile material was added during Proterozoic age orogenesis. The Nagavalli and Vamasadhara shear zones (NSZ and VSZ) demarcate the Domains 2 and 3 (Chetty 2001). Dobmeier and Raith (2003) on the other hand, subdivided EGB into several metamorphic provinces considering the similarity of petrological and isotopic signatures. The provinces were further subdivided into domains, which are distinguished on the basis of 'lithology, structure and metamorphic grade'. The nature of the mutual boundaries in the domainal or provincial classification is one important aspect. Several workers (Biswal and Sahoo 1998; Chetty 2001; Chetty et al. 2003) identified megalineaments in EGB from satellite imagery data although with limited ground checks. These lineaments broadly follow the domain/province boundaries which subdivide the EGB into several structural domains.

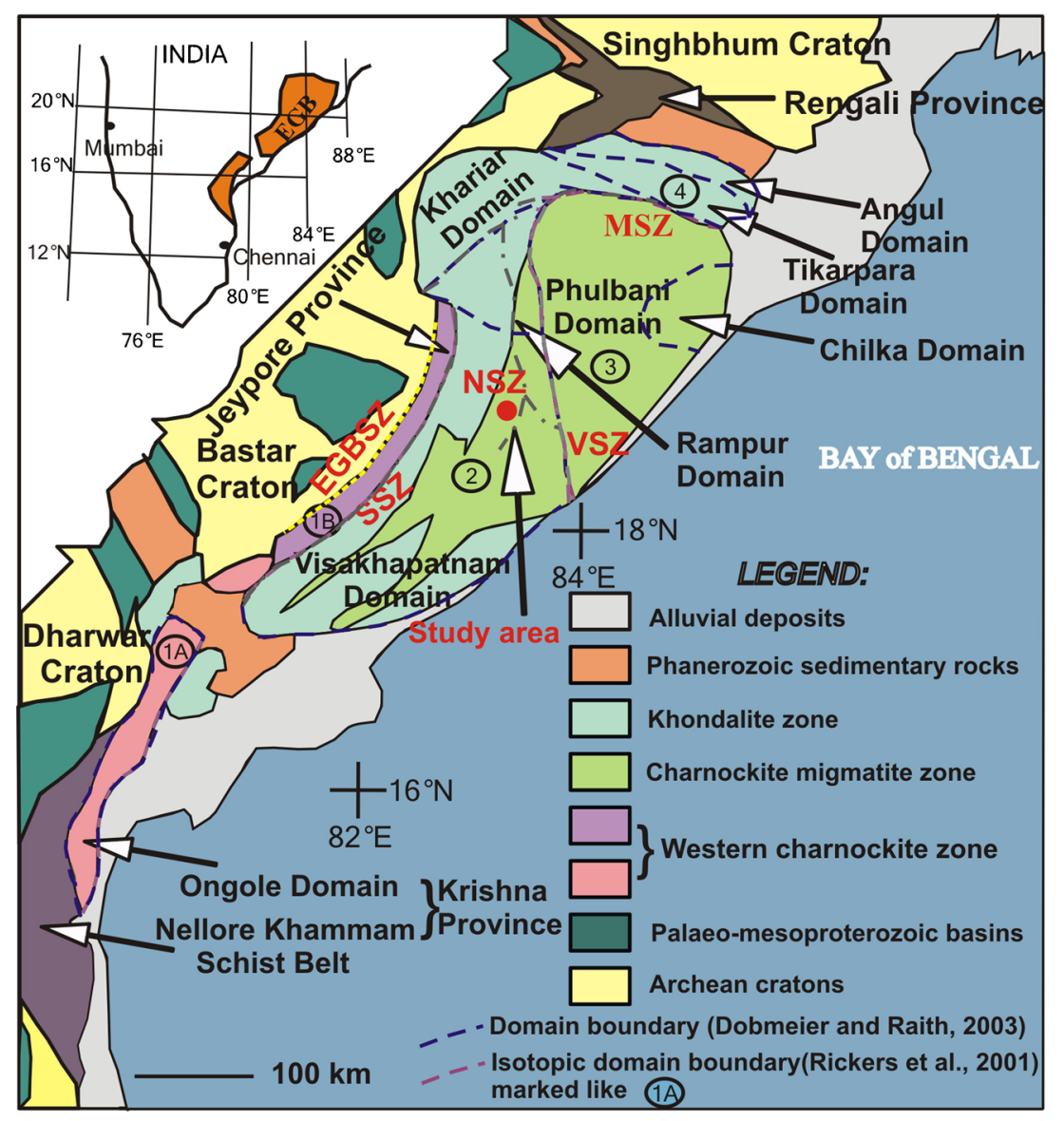

Figure 1. The geological setting of the field area in the Eastern Ghats Belt (EGB), India showing domainal divisions (after Rickers et al. 2001) and Province classification (after Dobmeier and Raith 2003) which are transected by major shear zones; Nagavalli Shear Zone (NSZ), Vamasadhara Shear Zone (VSZ), Sileru Shear Zone (SSZ) and Mahanadi Shear Zone (MSZ) after Chetty (2001). Eastern Ghats boundary shear zone is referred as EGBSZ. The nomenclature of Khondalite Zone, Charnockite Migmatite Zone and Western Charnockite Zone are after Ramakrishnan et al. (1998). The study area is marked in the figure. 
The structural domains signify the low-strain regions bounded by high-strain areas in the form of shear zones as suggested by Chetty (2001) and Chetty et al. (2003).

Orogenic shear zones develop as a result of large crustal displacement through a collisional event, which ranges from syn- to post-orogenic periods. The syn-orogenic shear zones are created close to the subduction front whereas, terrane boundary shear zone is created at the juxtaposition of slices of crust towards the overriding plate (Moresi et al. 2014). Several workers argue that thrusting of hot granulites along westward direction and welding of Proto Indian crust with EGB occurred during the Grenvillian through docking of hot UHT metamorphosed rocks over the Indian cratonic nucleus of Bastar Craton (Bhadra et al. 2004; Das et al. 2008). On the contrary, Biswal et al. (2007) indicated that regional metamorphism and fold-thrust structures with final juxtaposition of north-western part of EGB against Bastar Craton had taken place between 617 and 517 Ma along the Terrane Bounday Shear Zone (TBSZ). The other type is within terrane shear zone (Plujim et al. 1994). The crust moves and thrusts towards orogenic hinterland when the process of subduction ceases at plate margin or rather orogenic front. Depending upon the rate of accretion at the front, there may be an extension or compression (Cawood et al. 2009) in the back-arc area. This creates an environment for shear stress generation in the interior of the orogenic chain away from the collisional margin, and thus orogenic movements get accommodated by contractional or extensional shear zone development (Butler and Freeman 1996). As a result, the hinterland areas and orogen interiors are potential for generation of late- to post-orogenic shear zones. The shear zones develop in orogen interior by the stress generated at the subduction or collision front that permeated towards the interior. The orogen interior shear zones study in EGB is relevant to this background. Recently, Dasgupta et al. (2013) suggested prolonged accretion-collision history for central EGB that initiated at $1.5 \mathrm{Ga}$ and culminated at ca $0.90 \mathrm{Ga}$. The charnockite and granite emplacement took place about $0.98-0.96 \mathrm{Ga}$ and later collision and docking of Domain 2 onto the Bastar Craton occurred at about 0.9 Ga. The docking is manifested by generation or rejuvenation of shear zones in the charnockite and granitoid. Gupta (2012) suggested the late orogenic episodes of EGP were confined to province boundaries.

Chetty (2001) and Chetty et al. (2003) characterized the lineaments in EGB as ductile shear zones with limited field structural data. The most prominent of these is the Sileru Shear Zone (SSZ) marking the eastern boundary of WCZ (figure 1). The northernmost part of EGB is separated from the rest of the belt by the Mahanadi Shear Zone (MSZ) trending nearly E-W. Another major lineament is the Nagavalli-Vamasadhara Shear Zone (NVSZ) trending NNW-SSE that demarcates the boundary between the Visakhapatnam and Chilka domains of the Eastern Ghats Province (EGP). The lineaments broadly coincide with the river courses of Nagavalli-Vamasadhara. They inferred that the NVSZ is a result of a prolonged period of shear deformation marked by magmatism, migmatization, and development of ductile shear zones from 1450-850 Ma. The shear zones formed are steeply dipping with gently plunging lineations. The development of high-strain zones is accompanied by melting giving rise to leucogneiss in central parts of the shear zone. The shear zones are suggested to be the product of a transpressive movement in dextral nature. However, Mukhopadhyay and Basak (2009) pointed out the misfit of shear sense of the NSZ lineament compared to other tectonic lineaments of EGB and suggested more detailed study in this respect. The granitoids, on the contrary, are referred to be syntectonic with shearing at about $800 \mathrm{Ma}$ (Kovach et al. 1997). However, detailed structural, petrological and geochronological data with real tectonic significance of the lineaments are required to test the character of such domain/province boundaries. The interpretation of post-Grenvillian transpression tectonics for Chilka Lake granulites Dobmeier and Simmat (2002) is noteworthy in this context though the local structures have been explained by overall compressional regime without significant transpression (Das et al. 2012).

Alkaline plutonic complexes reported along the shear zones are interpreted to be related pull apart basin structures (Gupta et al. 2005; Das et al. 2008). However, few workers (Gupta et al. 2005; Mukhopadhyay and Basak 2009) questioned the timing of emplacement vis-à-vis shearing of these alkaline plutons. Biswal et al. (2007) correlated the alkaline magmatism with the fold-thrust belt structures when EGB was juxtaposed against the Bastar Craton. Anorthosite emplacement all over the Eastern Ghats Belt are interpreted to be emplaced much earlier than alkaline plutonic complexes (Dobmeier and Simmat 2002; Dobmeier 2006). Megacrystic granitoids are reported from Eastern Ghats province (EGP) at several localities (Mukhopadhyay and Bhattacharya 1997; Narayana et al. 1999; Simmat and Raith 2008) including along the NVSZ (Chetty et al. 2003). However, the emplacement of the granitoids, their deformation vis-à-vis metamorphism in context of the major shear zones are yet to be ascertained by systematic studies.

From the above backdrop, the study area occupies a key location to record the petrological and 
structural attributes of Nagavalli Shear Zone (NSZ) (figure 1). The study area falls within the Domain 2 (Rickers et al. 2001), in proximity to Domain 3 towards northeast and is transected by the NSZ. The present work envisages the emplacement of granitoids within the host migmatitic gneisses and metasedimentary rocks of EGB and exploring the style, magnitude, and events of polydeformation polymetamorphism and focuses on the status of NSZ through an integrated study of tectonothermal evolution of granitoid gneisses and associated granulites to resolve the ongoing debated issues. This is also essential to investigate along with the status of NSZ in context of petro-tectonic evolution of Eastern Ghats Belt.

\section{Petrological characteristics of granitoids and associated granulites}

The study area covers in and around Parvatipuram town in Andhra Pradesh, India (figure 2). It is included in the Domain 2 (Rickers et al. 2001) or Visakhapatnam domain (Dobmeier and Raith 2003) in the Eastern Ghats Belt. The area is situated close to the boundary between Domain 2 and Domain 3 which is transected by the Nagavalli Shear Zone (Chetty et al. 2003). The area covering almost $450 \mathrm{~km}^{2}$ has been mapped in the scale of 1:50,000 (figure 2). The study area exposes megacrystic granitoids, migmatitic gneisses, khondalite, and quartzite. There are principally two different varieties of granitoids: grey coloured and white coloured, based on the appearance in outcrop scale. The central part of this area is invaded by varieties of granitoids whereas the northwestern part is mostly covered by khondalites and quartzites; the eastern part is dominantly covered by migmatitic gneisses. However, khondalite and quartzite also occur in the eastern part and migmatites are associated with other rocks in the northwestern part of the area. Granitoids have sharp and intrusive contacts with charnockite-enderbites and migmatitic gneiss (leptynites) whereas the relation with khondalites is not exposed. The granitoids are macroscopically crudely foliated, to extremely sheared in nature. Both grey- and leuco-granitoids consist of euhedral/rectangular feldspar grains, which on continued deformation

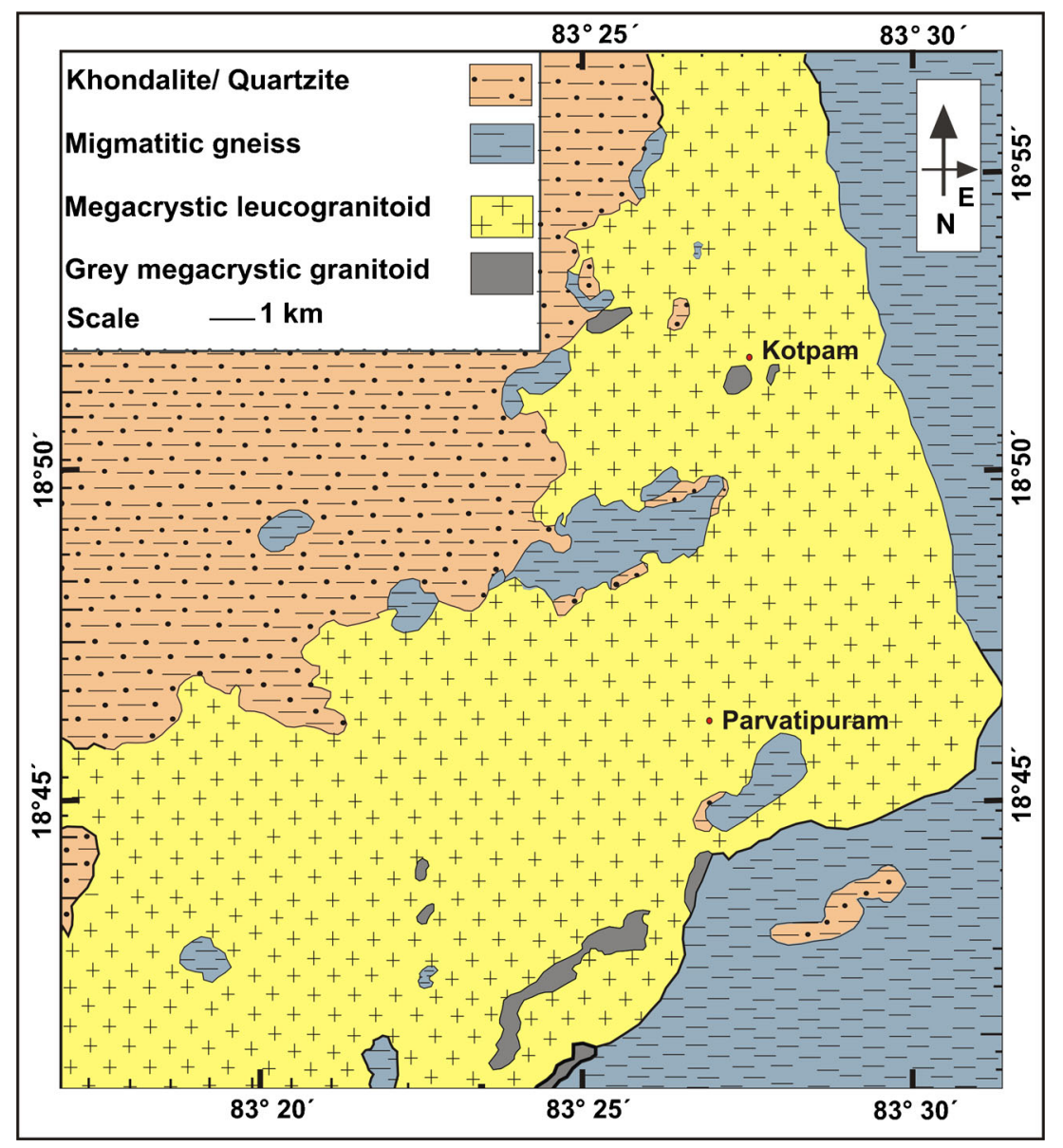

Figure 2. Disposition of rock types in the lithological map of the study area, originally mapped on 1:50,000 scale. 
transformed to augen shaped clasts in sheared granitoids and are characterized by alternately banded flattened light coloured feldspar clasts with dark coloured biotite and garnet rich bands. Henceforth the granitoids are referred as granitoid gneiss. The migmatitic gneisses consist of leptynitic gneiss (quartzo-feldspathic gneiss), massive charnockite-enderbites, migmatitic charnockite, and mafic granulites in outcrop scale. The leptynitic gneiss and both types of charnockites varies in thickness from meter to outcrop scale. However, mafic granulites occurr as bands or lenses within the migmatitic gneisses in tens of $\mathrm{cm}$ to meter scale in width. Apart from leptynites and charnockitesenderbites, khondalites (garnet-sillimanite-bearing quartzofeldspathic gneiss) and leucocratic variants of charnockite gneiss (orthopyroxene-bearing quartzofeldspathic gneiss) referred as orthopyroxene bearing migmatite also occur in a few exposures of migmatitic gneisses.

The leuco-granitoids are composed of translucent to opaque plagioclase and milky white alkali feldspar megacrysts (figure 3a). Crudely foliated to highly sheared varieties of leuco granitoids occurr in the area. The mineral constituents are plagioclase (18-22\%), alkali feldspar (10-15\%), quartz (16-20\%), garnet (5-15\%), orpthopyroxene (0-5\%), ilmenite (5-10\%), amphibole (0-2\%), clinopyroxene $(<2 \%)$, biotite $(12-16 \%)$ mostly. The fine grained matrix is composed of smaller alkali feldspar, plagioclase, biotite, opaque phase, and quartz aggregates. There is coarse garnet with meagre pyroxene and amphibole in it. Pyroxene is not the ubiquitous constituent of leucogranitoids. The rock is characterized by variable proportions of quartzofeldspathic leucosomal fractions. The length of feldspar megacrysts range from 4$7 \mathrm{~cm}$ in euhedral grains in relatively unsheared variety and may exceed $10 \mathrm{~cm}$ in stretched and sheared variety. Large clusters of garnet (2-6 $\mathrm{mm}$ ) with included opaque phase and biotite are rimmed by leucocratic melt fraction. The leucosomal patches form melt networks containing garnet and opaque phases and are variably elongated along the gneissic fabric depending upon the intensity of shear deformation. Dark coloured homogeneous decimetre-scale oval, drop to angular shaped mafic microgranular enclaves also occur (figure $3 \mathrm{~b}$ ). The enclaves contain orthopyroxene, clinopyroxene, quartz, feldspar, and locally garnet. In the sheared variety, the granitoids are characterized by the presence of mylonitic foliation that wraps around the feldspar augen. The sheared granitoid gneisses are characterized by the melanocratic and leucocratic bands, stretched along the shear foliation. The melanocratic bands are defined by biotite, garnet, orthopyroxene, and amphibole. Porphyroblastic garnets contain inclusions of quartz ilmenite, biotite, alkali feldspar, and rarely, plagioclase. Biotite and amphibole occur as an interstitial phase between the feldspar and quartz grains. Alkali feldspar-rich granitoids are devoid of pyroxene and contain euhedral biotite in interstitial space resulting in the matrix fraction with smaller quartz, plagioclase, and garnet grains.

Grey megacrystic granitoids also show variable deformation intensity from less deformed to highly sheared in nature. The mineral constituents are plagioclase (15-20\%), alkali feldspar (8-12\%), quartz $(12-15 \%)$, garnet $(8-20 \%)$, orpthopyroxene $(5-10 \%)$, ilmenite $(8-12 \%)$, amphibole $(2-5 \%)$, clinopyroxene (4-6\%), biotite (12-16\%) mostly. These are composed of greenish to grey feldspar megacrysts of 5-8 cm with melanocratic matrix made up of quartz, feldspar, garnet, pyroxene, quartz, and amphibole with greasy appearance. Henceforth, the grey megacrystic granitoids may also be referred to as megacrystic charnockites as orthopyroxene is the ubiquitous phase in it. Matrix quartz grains are polygonal inequigranular and interlocking with alkali feldspar and plagioclase grains. The plagioclase aggregates contain coarse subhedral amphibole inclusions. Plagioclase megacrysts are of euhedral to subhedral in shape (figure 3c). There are greyish green polymodal quartzofeldspathic aggregates interfingering in the matrix dominated by plagioclase. Coarse garnet and pyroxene grains are often rimmed by leucosomal fractions in matrix. Porphyroblastic garnet grains with inclusions of biotite, quartz, and opaque phase are surrounded by leucosomal melt fraction in 3-4\% of outcrop (figure 3d). Subhedral to anhedral plagioclase feldspars occur with recrystallized border in the sheared variety. Biotite flakes along with garnet clusters are stretched and flattened. There are bands and lenses of mafic microgranular enclaves within sharp to diffuse contact occuring within the leucocratic variety. Orthopyroxene-rich fractions contain lesser proportions of plagioclase clasts. Retrograde biotite replaces the ferromagnesian phases and locally amphibole also surrounds pyroxene grains.

Granitoids with gradational contacts between the above-mentioned varieties in outcrop scale have been observed consisting of $40-65 \%$ modal of euhedral to subhedral greyish green feldspar megacrysts. The matrix is composed of stretched up smaller feldspar, quartz, garnet, and biotite clasts.

There are broadly two types of leptynitic gneiss depending upon mineral assemblage and their modal proportion. The grey leptynitic gneiss is a mesocratic rock containing biotite, opaque phase, garnet along with quartzofeldspathic phase while the white leptynite consists of leucosomal quartzofeldspathic melt containing insignificant to low 


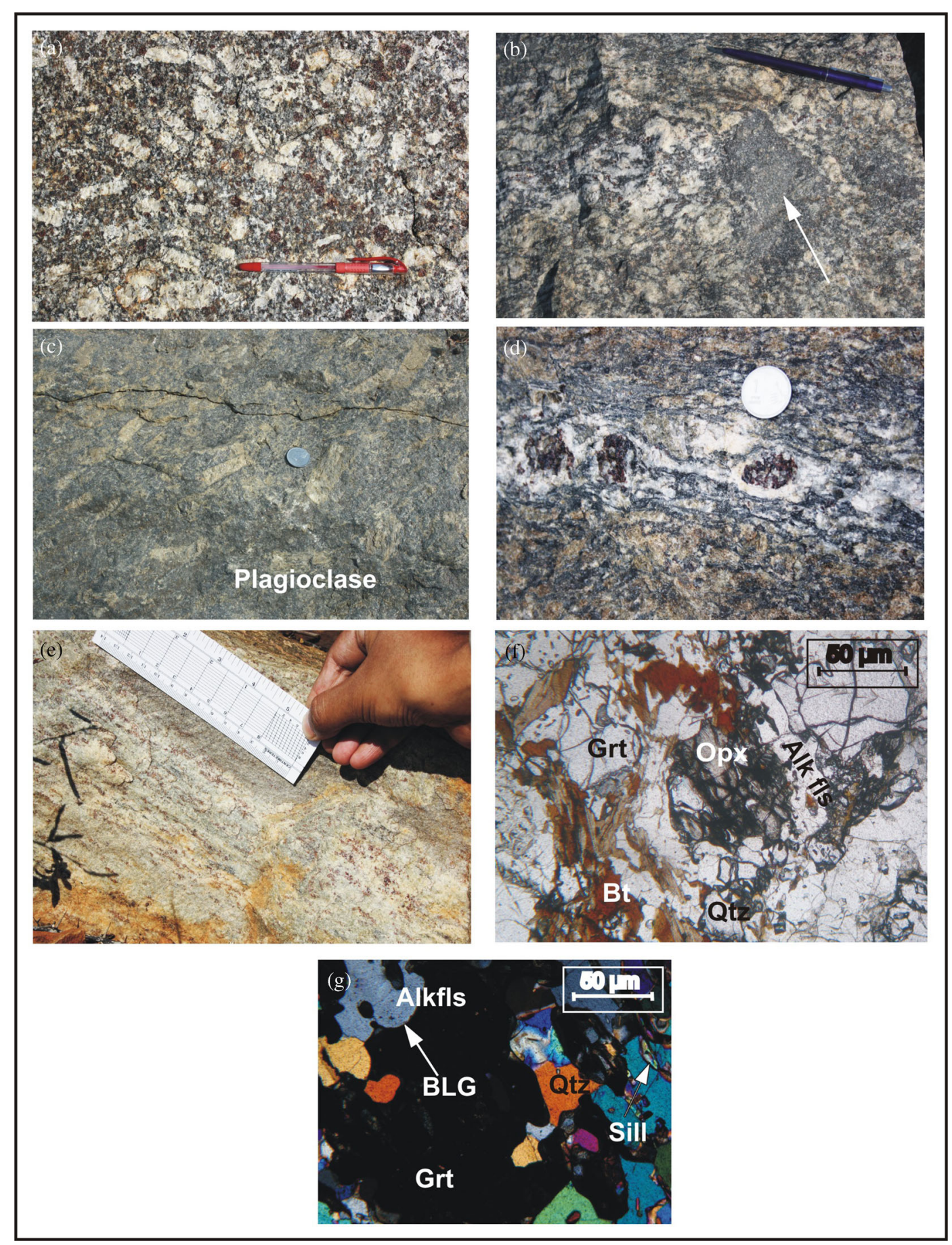

Figure 3. Mesoscopic and microscopic petrological characteristics of different rock types: (a) leucocratic variety of megacrystic with subhedral feldspar megacrysts in a matrix of biotite, feldspar and quartz with associated coarse garnet clasts. (b) Megacrystic leuco-granitoid with anhedral feldspar grains, quartzofeldspathic melt with matrix made up of garnet and biotite containing angular shaped mafic microgranular enclave (marked by arrow) with more or less sharp contact zone. (c) Euhedral to subhedral plagioclase in dark matrix of crudely foliated grey megacrystic granitoid. (d) Quartzofeldspathic mat surrounding garnet-rich clast (peritectic) in a deformed and sheared megacrystic graygranitoid. (e) Stretching lineation defined by garnet and biotite in leptynitic gneiss. (f) Coarse orthopyroxene (Opx) and garnet (Grt) grains are altered to retrogressive biotite in an orthopyroxene bearing migmatitic gneiss. The matrix shows occurrence of deformed alkali feldspar (Alk fls) and quartz (Qtz). (g) Bulging recrystallization (BLG) dominated deformation of alkali feldspar (Alk fls) at the contact of garnet (Grt) porphyroblast. Note the presence of quartz (Qtz) and sillimanite (Sill) needles in the matrix.

proportion of garnet porphyroblasts, opaque phase, and biotite. The concentration of quartz is variable in this leptynitic unit. Garnet porphyroblasts in leptynitic gneiss contain inclusions of biotite and quartz with occasional presence of opaque minerals. In the white leptynite, quartz forms 
monocrystalline ribbon of $\mathrm{L} / \mathrm{W}>10: 1$. Both the variants of leptynites are characterized by stretched and lineated garnet and opaque minerals $2-5 \mathrm{~mm}$ in length (figure $3 \mathrm{e}$ ). In the grey leptynite, melanocratic layers consist 30-40\% modal biotite, where the porphyroblastic garnet is concentrated both in $\mathrm{cm}$ scale biotite richer fraction and leucosomal quartzofeldspathic fraction.

There are broadly two varieties of charnockite in the host lithotypes. They are migmatitic charnockite and massive charnockite-enderbite gneiss. Migmatitic charnockite is a heterogeneous rock composed of alternate orthopyroxene, biotite, opaque phase, and minor garnet bearing melanocratic layers and leucocratic quartz, alkali feldspar, and plagioclase lath bearing layers in decreasing order of abundance in outcrop. The contact nature between the leptynitic gneiss and migmatitic charnockite is diffuse in nature. Porphyroblastic orthopyroxene develops boudins oriented along the gneissic foliation in the migmatitic charnockite. Alkali feldspars mostly dominate in between the polycrystalline quartz ribbons. The ribbons show length versus width ration $(\mathrm{L} / \mathrm{W})$ $>6: 1$ and monocrystalline quartz ribbons with $\mathrm{L} / \mathrm{W}<5: 1$ under microscope. Observed aggregate shape preferred orientation (ASPO) is the result of dynamic recrystallization. Coarse orthopyroxene and garnet are fractured and filled up with late biotite (figure 3f). Massive charnockite enderbitic gneisses are greasy melanocratic, heterogeneous rock with orthopyroxene, lesser amount of clinopyroxene, feldspar, quartz, and garnet. Discontinuous quartzofeldspathic aggregates of $\mathrm{mm}$ scale create diffuse gneissic pattern in this lithoytype with aggregate shape preferred orientation.

Khondalite is interbanded with quartzite in decimeter-scale to outcrop-scale. Khondalite is gneissic with alternate porphyroblastic garnet, biotite, sillimanite bearing fraction, and quartz, feldspar bearing fraction. Subgrains of alkali feldspar, garnet, and quartz show inequigranular interlocking texture. Alkali feldspar dominated matrix contains clusters of sillimanite. Quartz forms ribbons with aspect ratio $>6: 1$ in some cases. Bulging recrystallization (BLG) mechanism dominates in the feldspars causing deformation processes in contact with garnet (figure $3 \mathrm{~g})$. They show very coarse sillimanite needles occurring disseminated and aligned parallel in the quartz-alkali feldspar matrix and somewhere create coarse aggregate. Garnets contain biotite, quartz, and opaque inclusions and are highly fractured. Quartzite shows foliation planes defined mostly by stretched and flattened quartz with garnet and biotite flakes. Opaque phases are present in both of them. There are khondalite lenses found within the leptynitic country rock in our study area.
Bands and lenses of melanocratic medium to coarse grained mafic granulite enclaves occur both in migmatitic gneisses, quartzites, and khondalites.

\section{Geochemistry of granitoids}

XRF analysis of selected samples of granitoids (leucocratic and grey variety) was done from National Centre for Earth Science Studies (NCESS), (Ministry of Earth Sciences, Government of India), Thiruvananthapuram by Bruker model S4 Pioneer sequential wavelength-dispersive X-ray spectrometer under pressed pellet and presented in table 1.

Both the varieties of granitoids, viz., leucogranitoid and grey granitoid were taken for geochemical classification. The oxide data of rocks were plotted in QAP diagram of Streckeisen (1974) after normalization on catanormal basis. Grey granitoids plot in the monzogranitic field along with the leucogranitoids (figure 4a). Some of the plots cluster at the granodiorite monzogranite boundary. Feldspar triangle plot devised by O'oconnor (1965) has also been utilized using CIPW basis to classify the rocks bearing $>10 \%$ quartz based on feldspar ratios. Megacrystic leuco and grey granitoids are scattered in quartz monzonitic field (figure $4 \mathrm{~b}$ ). The mineralogy may coincide with Krich granodiorite as discussed in O'oconnor (1965).

Plutonic coarse-grained rocks may be redefined using alkali content $\left(\mathrm{Na}_{2} \mathrm{O}+\mathrm{K}_{2} \mathrm{O}\right.$ wt\%) against $\mathrm{SiO}_{2}$ wt\% diagram modelled by Middlemost (1994). Granitoids fall in the diagram on the subalkaline field (figure 4c) and are principally clustered around mean composition of granodiorite. The leucogranitoid shows much more compositional scatter than grey variety. The leucogranitoid plots from granodiorite to granite, whereas grey variety spreads from granodiorite to granodioritetonalite transitional composition. The granitoids are geochemically classified according to Frost et al. (2001). Ferroan index (figure 4d) denotes that both the granitoids are mostly ferroan in nature, although each of the respective variety falls in magnesian field. MALI (Modified alkali lime index) was defined by Frost et al. (2001) to match common plutonic compositional trends with calcic, calcalkalic, alkali-calcic, and alkalic trends. For any given suite of rock MALI increases with increasing $\mathrm{SiO}_{2}$ wt\%. When plotted, this index shows a crude trend of the granitoids from calcic to calc alkali field (figure 4d). This trend is much stronger for the megacrystic charnockite. Granitoids are plotted in ASI versus A/NK diagram (figure 4d). Aluminium saturation index (ASI) defines the molecular ratio $\mathrm{Al} /(\mathrm{Ca}-1.67 \mathrm{P}+\mathrm{Na}+\mathrm{K})$ (Frost et al. 2001). Corundum normative is indicated for ASI $>1$ for excess aluminum that is not 
Table 1. Major elements (wt\%) and trace elements (ppm) composition of megacrystic leuco- and grey-granitoids from study area.

\begin{tabular}{|c|c|c|c|c|c|c|c|}
\hline \multirow{2}{*}{$\frac{\text { Sample no. }}{\text { Lithology }}$} & PV179A & PV203 & PV137 & PV159 & PV10D2 & PV220 & PV166 \\
\hline & \multicolumn{4}{|c|}{ Megacrystic leuco-granitoid } & \multicolumn{3}{|c|}{ Megacrystic grey-granitoid } \\
\hline $\mathrm{SiO}_{2}$ & 67.81 & 74.469 & 67.17 & 68.22 & 65.24 & 65.36 & 65.7 \\
\hline $\mathrm{TiO}_{2}$ & 0.86 & 0.258 & 0.84 & 1.14 & 1.8 & 1.14 & 0.63 \\
\hline $\mathrm{Al}_{2} \mathrm{O}_{3}$ & 15.07 & 13.581 & 14.66 & 13.76 & 12.55 & 15.07 & 15.73 \\
\hline $\mathrm{MnO}$ & 0.06 & 0.03 & 0.07 & 0.09 & 0.14 & 0.11 & 0.05 \\
\hline $\mathrm{Fe}_{2} \mathrm{O}_{3}$ & 4.38 & 1.817 & 4.85 & 5.94 & 8.27 & 6.3 & 4.73 \\
\hline $\mathrm{CaO}$ & 4.34 & 2.082 & 2.96 & 4.02 & 4.73 & 3.77 & 3.29 \\
\hline $\mathrm{MgO}$ & 1.18 & 0.223 & 0.94 & 0.77 & 1.05 & 1.17 & 1.56 \\
\hline $\mathrm{Na}_{2} \mathrm{O}$ & 1.79 & 2.473 & 1.67 & 1.95 & 1.95 & 1.7 & 1.56 \\
\hline $\mathrm{K}_{2} \mathrm{O}$ & 3.54 & 4.47 & 5.82 & 3.25 & 3.23 & 4.53 & 5.58 \\
\hline $\mathrm{P}_{2} \mathrm{O}_{5}$ & 0.2 & 0.066 & 0.31 & 0.37 & 0.72 & 0.39 & 0.26 \\
\hline $\mathrm{V}$ & 67 & 25 & 50 & 65 & 72 & 78 & 64 \\
\hline $\mathrm{Cr}$ & ND & 17 & ND & 3 & ND & 17 & 21 \\
\hline $\mathrm{Co}$ & 23 & 5 & 21 & 27 & 34 & 25 & 23 \\
\hline $\mathrm{Ni}$ & 8 & 6 & 7 & 4 & ND & 11 & 17 \\
\hline $\mathrm{Ga}$ & 19 & ND & 14 & 14 & 14 & 14 & 16 \\
\hline $\mathrm{Rb}$ & 165 & 56 & 231 & 103 & 68 & 155 & 178 \\
\hline $\mathrm{Sr}$ & 242 & 429 & 207 & 158 & 138 & 274 & 322 \\
\hline $\mathrm{Y}$ & 36 & 77 & 46 & 40 & 98 & 71 & 20 \\
\hline $\mathrm{Zr}$ & 342 & 48 & 366 & 443 & 618 & 422 & 275 \\
\hline $\mathrm{Nb}$ & 17 & 190 & 18 & 25 & 52 & 23 & 4 \\
\hline $\mathrm{Ba}$ & $0.11 \%$ & 31 & $0.14 \%$ & 635 & 480 & $0.16 \%$ & $0.23 \%$ \\
\hline $\mathrm{La}$ & 128 & 245 & 94 & 78 & 118 & 86 & 169 \\
\hline $\mathrm{Ce}$ & 232 & 12 & 169 & 137 & 229 & 153 & 287 \\
\hline $\mathrm{Sm}$ & 12 & 48 & 9 & 10 & 13 & 8 & 14 \\
\hline $\mathrm{Th}$ & 52 & 57 & 13 & 1 & ND & ND & 74 \\
\hline L.O.I. & 0.51 & 0.47 & 0.40 & 0.22 & 0.04 & 0.14 & 0.47 \\
\hline
\end{tabular}

Note: Error in Ga content is \pm 0.4 ppm except for one sample (4 ppm). ND: Below detection limit.

accommodated in feldspar. Aluminous minerals like muscovite, sillimanite, and garnet are present in the rocks because of strongly peraluminous nature of the rocks. Ca would be excess in rock that could be accommodated in feldspar when ASI $<1$ and $(\mathrm{Na}+\mathrm{K}) / \mathrm{Al}<1.0$. Therefore, phases like calcic amphibole or calcic pyroxenes may be present in the rocks. For $\mathrm{ASI}<1$ and $(\mathrm{Na}+\mathrm{K}) / \mathrm{Al}>1.0$, the rocks would have excess alkali element than could be accommodated in feldspars. ASI versus A/NK plots signify metaluminous to weakly peraluminous character for grey granitoids and weakly peraluminous nature of the white granitoids. Grey granitoids show higher modal proportation of amphibole and pyroxene. Ga-enrichment discrimination diagram (Whalen et al. 1987) has been used to classify the granitoids (figure 4e). However, the employed analytical method has major uncertainty in the Ga content. Thus, the granitoids are more or less calcic to calc alkaline, metaluminous to weakly peraluminous suite of rocks, which shows iron enrichment and possibly originated as I- and S-type in character.

\section{Imprints of structural fabrics in regional scale}

The planar and linear structural elements, which are key indicators for deciphering the structural evolution of that have been studied systematically and are illustrated in figure 5. The detailed structural mapping was carried out in 1:50,000 scale covering approximately $450 \mathrm{~km}^{2}$ (figure 5). The area exposes with granitoid rocks hosted in a suite of granulite rocks. The primary sedimentary banding $\mathrm{S}_{0}$ could not be identified in metasediments like quartzite-khondalite units in host granulites either in outcrop-scale or under microscopic study. Therefore, deformational signatures related to transformation from $\mathrm{S}_{0}$ to $\mathrm{S}_{1}$ are completely lost due to successive deformation and high-grade metamorphism producing partial melting. The $\mathrm{S}_{1}$ fabric is rarely preserved in the host migmatitic gneisses in outcrop-scale, which is a product of $\mathrm{D}_{1}$ deformation. The development of $\mathrm{S}_{1}$ fabric and subsequent folding of it producing earliest recognizable $F_{1}$ fold in $D_{2}$ deformation are only 


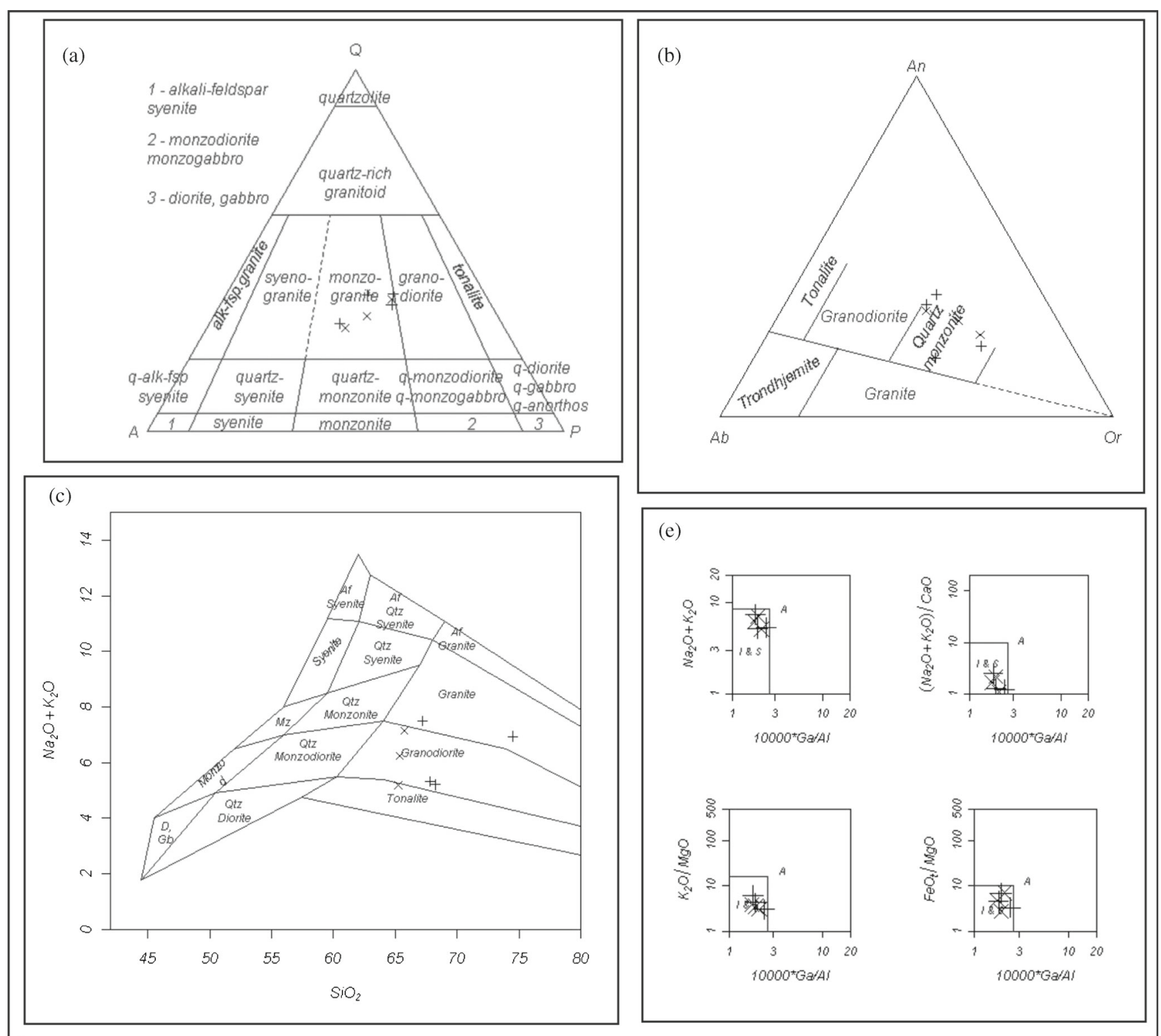

(d)
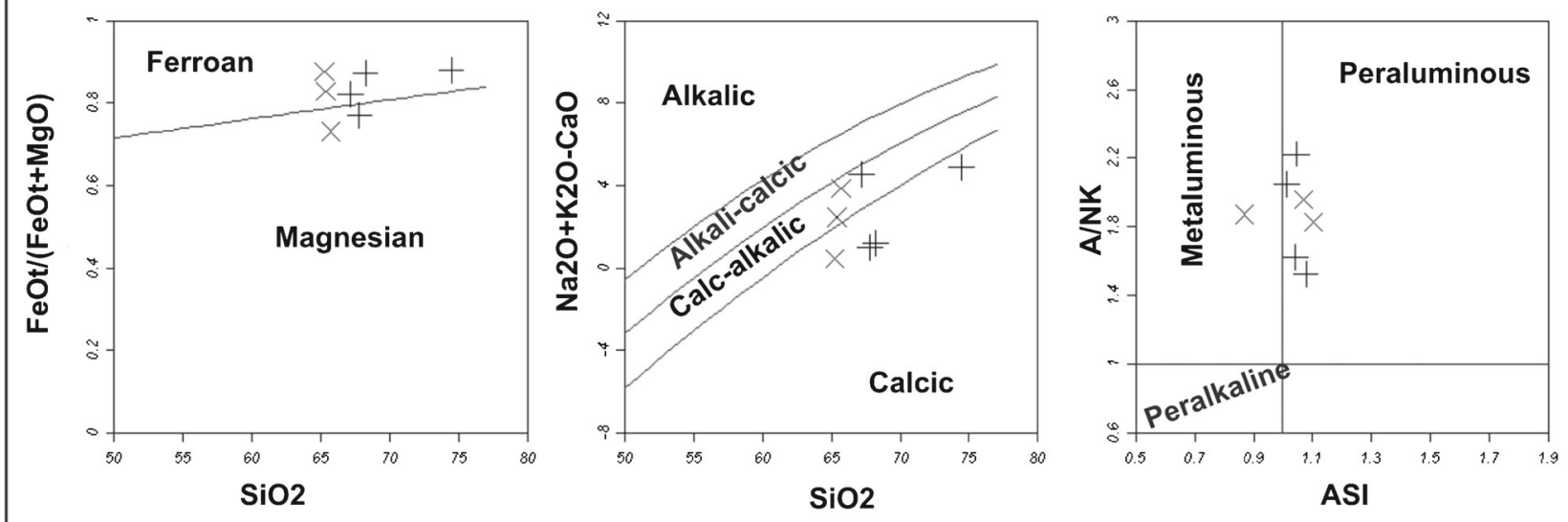

Figure 4. (a) Representative analysis defined in diagram of Streckeisen (1974). Megacrystic leucogranitoid is shown in by + , grey megacrystic granitoids by $\mathrm{x}$. The data for all the analyses used in the diagrams are given in table 1 . (b) Analytical data plotted in feldspar triangle plot (O'oconnor 1965). (c) TAS diagram plotted with representative analysis defined by Middlemost et al. (1994). (d) Classification diagram of Frost et al. (2001) with similar notation with representative samples (a). (e) Representative samples classified by Whalen et al. (1987) with same notation used as (a). 


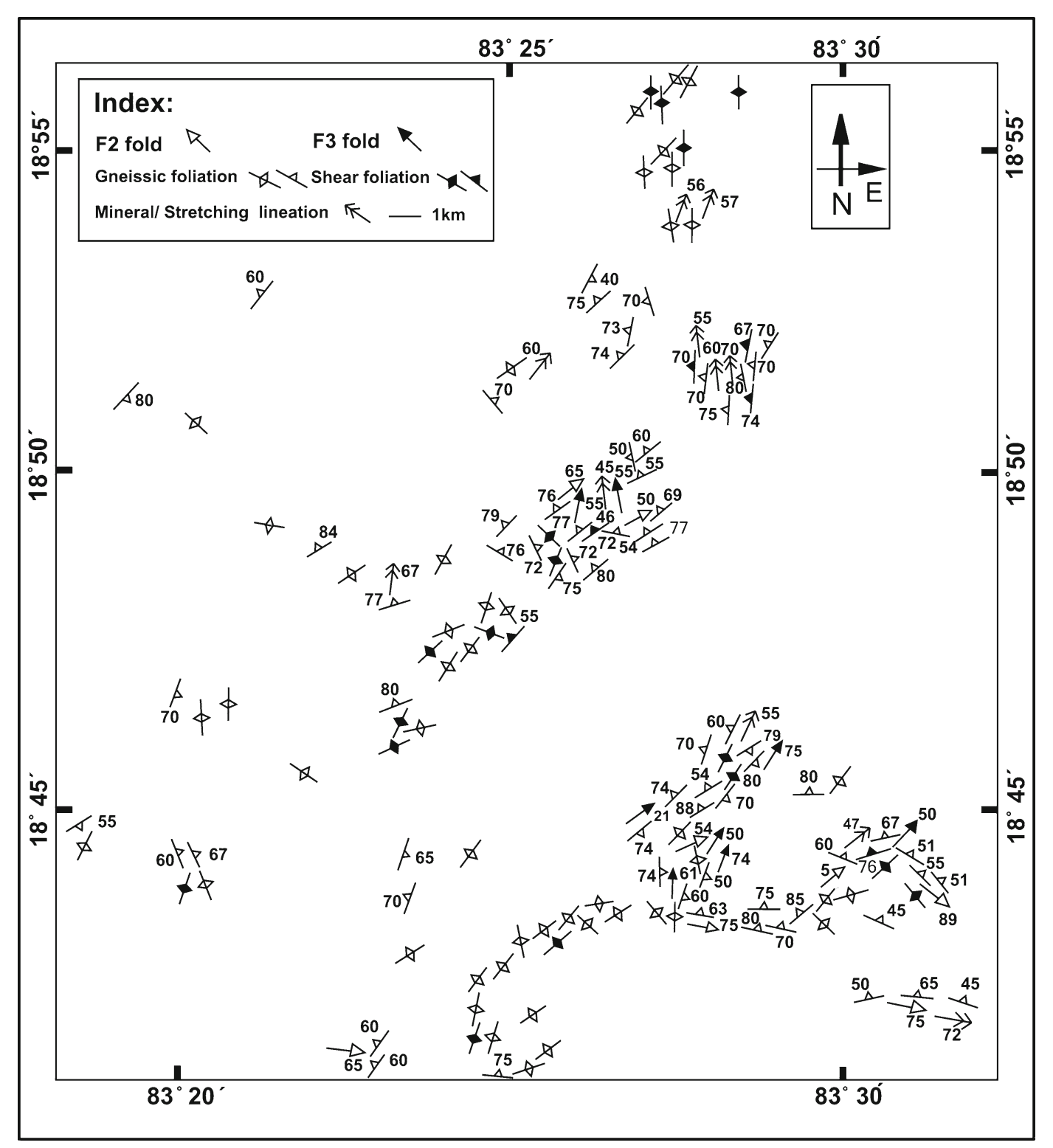

Figure 5. The structural map of the study area showing different structural fabrics and lineations, originally mapped on 1:50,000 scale.

preserved in the outcrop-scale and will be discussed further in next section. The characteristic gneissic foliation occurs as regional penetrative planar fabric in all host granulites, which is designated here as $\mathrm{S}_{2}$ in $\mathrm{D}_{2}$ deformation. Granitoids bear earliest fabric as crude gneissosity, which is conformable to this $S_{2}$ gneissic foliation in the host migmatites and hence the granitoids may be referred to as post $S_{1}$ intrusion. The gneissic foliation mostly trend northeast-southwest in the southern part and swings to north-south in the northern part. The foliations have moderate to steep dip, and in several places it is nearly vertical. Absence of any marker units and only presence of gneissosity in granitoids and associated granulites make the interpretation of structural disposition very difficult. For better understanding and representation of the regional structural disposition, the strike line sketch map has been prepared (figure 6). The quartzite-khondalite unit enveloped with banded migmatitic gneisses and granitoids in the southern part have been tightly folded $\left(\mathrm{F}_{2}\right)$ in regional scale with broad northeast-southwest axial trace. The $\mathrm{S}_{2}$ gneissosity, the form surface of the tight $\mathrm{F}_{2}$ fold, has been transposed tectonically with the axial plane of the $\mathrm{F}_{2}$ fold and locally the planar fabric exhibits transposed $\mathrm{S}_{2} / \mathrm{S}_{3}$ gneissosity. The overall regional fold pattern represents an upright to steeply inclined with vertical to steeply plunging synform. The axial plane of the regional fold is curved implying a superposed nonplane folded structure due to subsequent deformation. The axial trace of this later fold $\left(\mathrm{F}_{3}\right)$ roughly strikes along north-south with fold axis plunging 


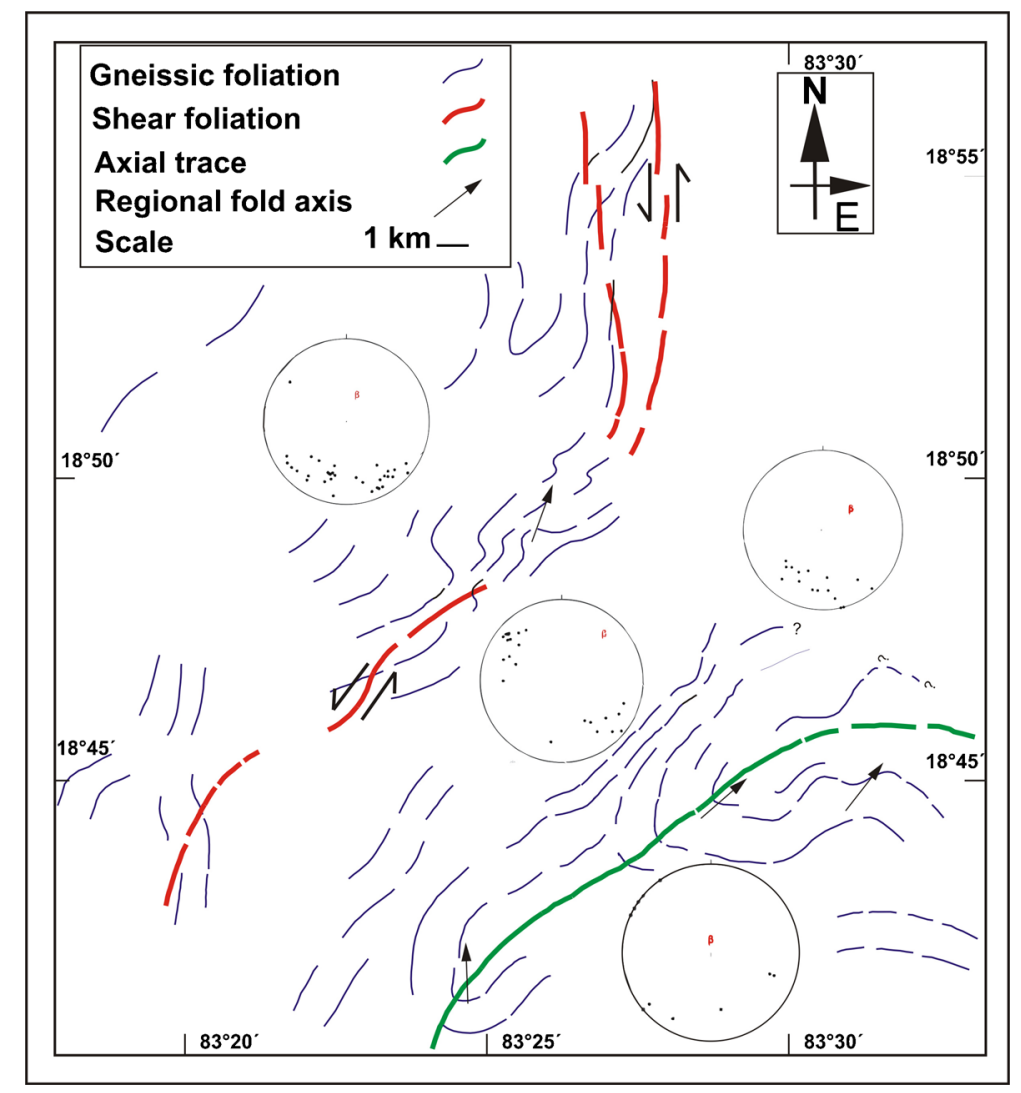

Figure 6. Sketch map showing the systematic variation and relationship of different generations of planar fabrics. Sectorwise $\beta$-diagrams are included in the map.

towards NE. The sectorwise $\beta$ plot of the gneissosity $\left(\mathrm{S}_{2}\right)$ demonstrate how the fold axis of regional $\mathrm{F}_{2}$ has been modified with later deformation. The regional modified $\mathrm{F}_{2}$ (or $\mathrm{F}_{3}$ ) changes its attitude from vertical (plunge $80^{\circ}$ ) to $23^{\circ} \rightarrow 41^{\circ}$ and finally it plunges $55^{\circ}$ towards $54^{\circ}$. The systematic variation of the fold axes reveals the nature of superposed structure as non-plane non-cylindrical fold. However, the other part of the study area is covered with crudely foliated granitoids and preserve less discernible fold structures except for a few asymmetric to tight folds. The $\mathrm{S}_{2}$ gneissic foliation deforms differently and strikes broadly northeastsouthwest to north-south direction and locally preserved fold structure. The regional-scale anastomosing shear zone with prominent sinistral sense cuts across the earlier folded $\mathrm{S}_{2}$ gneissic foliation in the granitoids and migmatitic gneiss that runs from north toward south through granitoids and swings towards south-southwest in southern part of the study area through granitoids and migmatitic gneiss. The imprints of mylonitic foliation on earlier gneissic foliation $S_{2}$ in this shear zone suggest a separate deformation after $\mathrm{F}_{2}$. These shear foliations are either vertical or steeply dipping $\left(\sim 70^{\circ}\right)$ towards west to northwest with conspicuous steeply plunging stretching lineation. Few dextral shear bands oriented either along NE-SW trend or $\mathrm{E}-\mathrm{W}$ trend conjugate in nature with the dominant mylonitic foliation, dipping westerly to vertical, have been observed in outcrop-scale.

\section{Development of structural elements from mesoscopic to microscopic scale}

Four episodes of deformational events have been studied in this, viz., $\mathrm{D}_{1}, \mathrm{D}_{2}, \mathrm{D}_{3}$, and $\mathrm{D}_{4}$. The earliest planar fabric recognized in the host migmatitic gneisses is $S_{1}$ which is the result of $D_{1}$ deformation. The deformational mechanism could not be deciphered either from outcrop studies or by microscopic investigation. Therefore, first recognizable fold, $\mathrm{F}_{1}$ has been identified in the migmatitic gneisses on $\mathrm{S}_{1}$ in $\mathrm{D}_{2}$ event. $\mathrm{F}_{2}$ and $\mathrm{F}_{3}$ folds are developed in $\mathrm{D}_{3}$ and $\mathrm{D}_{4}$ deformation respectively. $\mathrm{D}_{1}$ and $\mathrm{D}_{2}$ deformations have been studied in meso- to microscopic scale whereas the $\mathrm{D}_{3}$ and $\mathrm{D}_{4}$ have been studied from micro- to megascopic scale. $\mathrm{D}_{1}$ and $\mathrm{D}_{2}$ deformations are the product of prograde to peak metamorphic condition. However, $\mathrm{D}_{3}$ and $\mathrm{D}_{4}$ are the result of post-peak metamorphic condition. 


\section{$5.1 D_{1}$ event}

First recognizable planar fabric, $\mathrm{S}_{1}$, identified only in the host migmatitic gneisses is the thinly laminated quartzofeldspathic units (figure 7a), which may be predicted as incipient melting during prograde metamorphic $\left(\mathrm{M}_{1}\right)$ condition. Biotitequartz-feldspar is the possible prograde mineral assemblage as deciphered from the inclusion texture within garnet in gneissic rocks. Microstructures, textures as well as mesoscopic structures relating to this prograde metamorphic history is completely lost and could not be quantified properly. Therefore, earliest $S_{1}$ fabric has been formed in $\mathrm{D}_{1}$ event in pre-peak metamorphic condition in host migmatitic gneisses.

\section{$5.2 D_{2}$ event}

The $\mathrm{S}_{1}$ planar fabric has been deformed showing rootless tight to isoclinal $F_{1}$ folds (figure $7 \mathrm{a}$ ) in $\mathrm{D}_{2}$

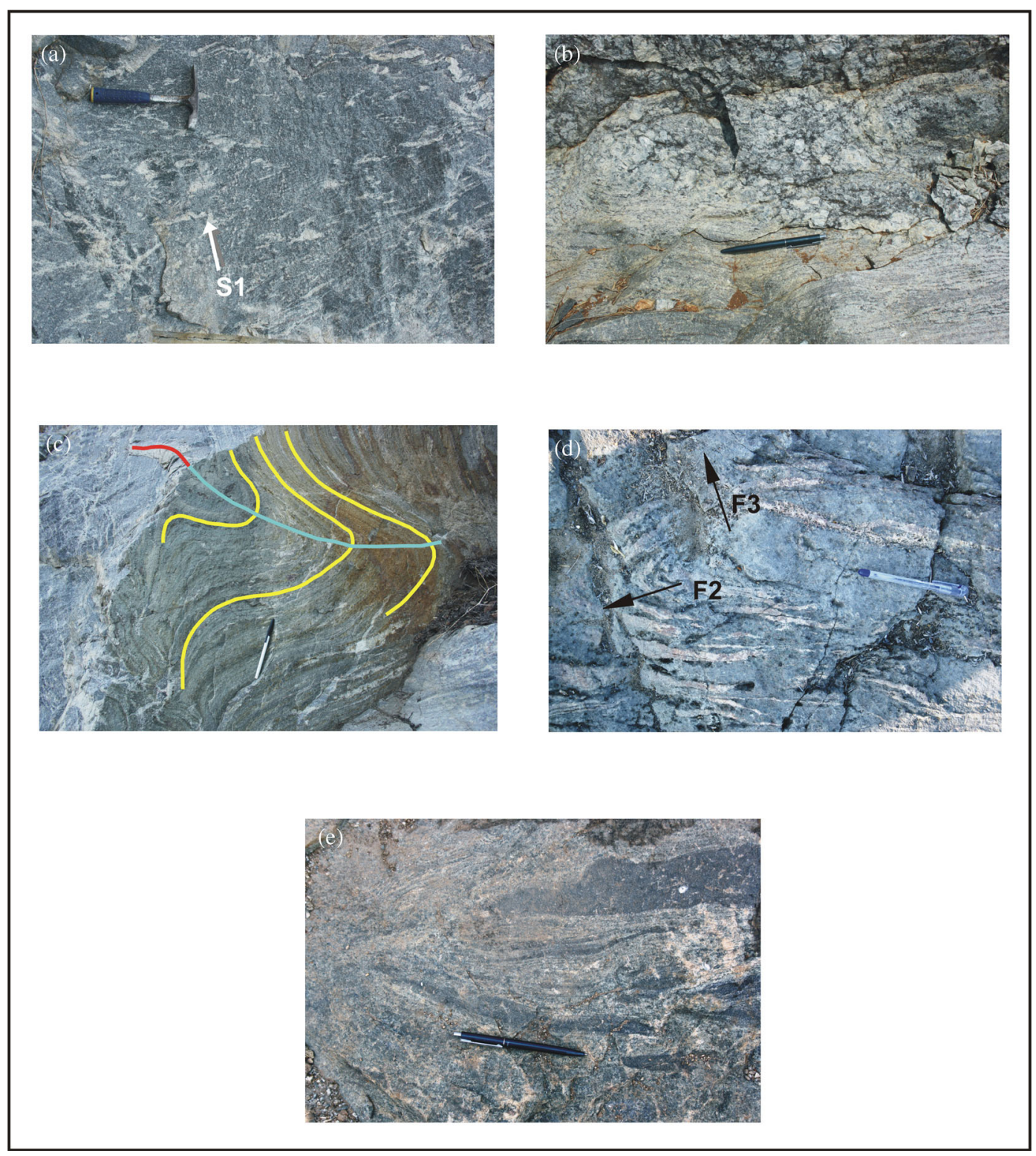

Figure 7. Outcrop scale structural features in the lithotypes. (a) The $\mathrm{S}_{1}$ compositional bands occuring in the form of rootless isoclinal folds in a host of migmatites, where the $\mathrm{S}_{2}$ gneissosity is axial planar to the folded $\mathrm{S}_{1}$ fabrics. (b) $\mathrm{S}_{2}$ gneissic foliation in leptynitic gneiss and crudely foliated with stretched and flattened feldspar clasts having conformable relationship. (c) Non-plane superposed fold defined by $\mathrm{S}_{2}$ gneissic foliation of quartzofeldspathic gneiss resulting from interference caused by $\mathrm{D}_{3}$ and $\mathrm{D}_{4}$ deformation. $\mathrm{S}_{2}$ gneissic foliation and axial plane are marked in the figure. Note the curvature and modification of axial plane on vertical and on near horizontal plane. (d) Isoclinal folding on $\mathrm{S}_{2}$ gneissic foliation of migmatitic gneisses showing $\mathrm{F}_{2}$ and $\mathrm{F}_{3}$ folds. (e) Tight to isoclinal fold on mafic bands parallel to the $\mathrm{S}_{2}$ gneissic foliation of migmatitic gneiss. Mafic bands are boudinaged on the limb. Note that the $\mathrm{S}_{2}$ foliation is transposed with the axial plane $\mathrm{S}_{3}$. 
deformation. The characteristic penetrative gneissic foliation $\mathrm{S}_{2}$ has been developed in all the host granulites during $\mathrm{D}_{2}$ deformation, which is axial planar to these rootless isoclinal to tight folds on $\mathrm{S}_{1}$. The earlier fabric $\mathrm{S}_{1}$ has been transposed with the axial planar foliation $\mathrm{S}_{2}$. High-grade deformations accompanying partial melting have obliterated the earliest $S_{1}$ fabric and $F_{1}$ folds in the granulites. The $\mathrm{F}_{1}$ folds on $\mathrm{S}_{1}$ fabric are seldom preserved in the host migmatitic gneisses. As a result, $\mathrm{S}_{2}$ gneissic foliation is the characteristic penetrative fabric in host granulites in meso- to megascopic scale. The gneissosity in migmatites is defined by garnetiferous mesocratic layers alternating with leucocratic quartzofeldspathic layers. In khondalites, on the other hand, $\mathrm{S}_{2}$ fabric is characterized by alternate bands of mesocratic garnet-biotite-sillimanite bands and leucocratic quartzofeldspathic bands. Coarse grained megacrystic granitoids occur within migmatitic gneiss and quartzite-khondalites as massive to crudely foliated nature. Granitoids bear the earliest planar fabric as crude gneissic foliation, which is conformable with $\mathrm{S}_{2}$ fabric in the host granulites. Plagioclase megacrysts and the matrix minerals in the well deformed granitoids are flattened and elongated showing a crude foliation, which is parallel and conformable with the $\mathrm{S}_{2}$ foliation in the adjacent leptynitic gneiss (figure $7 \mathrm{~b}$ ). Thus the granitoids are deformed and metamorphosed and predictably emplaced pre- to syn- $\mathrm{D}_{2}$ event.

Porphyroblastic garnets have been stabilized in granitoids and in leptynitic migmatitic gneiss in peak metamorphic condition $\left(\mathrm{M}_{2}\right)$. Garnetsillimanite bearing assemblage has been stabilized in khondalite defining the gneissic foliation. $\mathrm{S}_{2}$ gneissic fabric is defined by garnetiferous layers in garnet bearing granulites. Porphyroblastic garnets are mantled by the quartzofeldspathic mat in metagranitoids and associated leptynitic gneisses suggesting melt present peak metamorphic condition $\mathrm{M}_{2}$ during $\mathrm{D}_{2}$ deformation.

\section{$5.3 D_{3}$ event}

The pervasive gneissic foliation, $\mathrm{S}_{2}$ in the host granulites and the crude gneissic foliation $\left(\mathrm{S}_{2}\right)$ in metagranitoids systematically varies in regional scale as discussed in the earlier section. In the southern part, the $\mathrm{S}_{2}$ fabric in the successive litho units of khondalites, quartzites, migmatitic gneisses, and metagranitoids exhibit regional $\mathrm{F}_{2}$ folding with NE-SW axial plane (figure 6). The regional folds are tight, gently to steeply plunging $\left(23^{\circ} \rightarrow 55^{\circ}\right)$ to vertical and upright to inclined synform. The curved axial plane of this regional $\mathrm{F}_{2}$ fold is the result of subsequent $\mathrm{D}_{4}$ deformation, which modified the $\mathrm{F}_{2}$ fold axis differently producing non-plane non-cylindrical superposed folds. In the northern part, the folds are less discernable in regional scale on $S_{2}$ gneissic foliation and exhibit systematic strike variation of deformed $\mathrm{S}_{2}$ from $\mathrm{NE}-\mathrm{SW}$ to $\mathrm{N}-\mathrm{S}$ direction. In outcrop-scale, the $\mathrm{S}_{2}$ fabric is deformed exhibiting similar style of folding in host granulites. Near Ullibhadra, on near vertical surface the $F_{2}$ fold is evident on $S_{2}$ gneissic fabric. The $\mathrm{S}_{2}$ gneissic layering in the leptynitic gneiss has been deformed forming inclined gently plunging folds (figure $7 \mathrm{c}$ ). Axial plane $\left(\mathrm{S}_{3}\right)$ of this fold strikes $30^{\circ}$ dipping $35^{\circ}$ easterly. Attitude of the axial plane changes from inclined to horizontal orientation. Thus the axial plane of the $\mathrm{F}_{2}$ fold is curved or folded again forming non-plane cylindrical superposed structure. Axial plane changes its dip from $35^{\circ}$ to nearly $0^{\circ}$. Fold axis is gently plunging NE. Near Gadabavalasa, $\mathrm{S}_{2}$ gneissic foliation in migmatititc gneiss is isoclinally folded $\left(\mathrm{F}_{2}\right)$ and is transposed with newly developed axial planar fabric $\left(\mathrm{S}_{3}\right)$ forming a composite $\mathrm{S}_{2} / \mathrm{S}_{3}$ gneissic foliation (figure $7 \mathrm{~d}$ ). This $\mathrm{F}_{2}$ fold is modified and deformed again by later deformation. The mafic bands within leptynitic gneiss has been refolded $\left(\mathrm{F}_{3}\right)$ where the transposed $\mathrm{S}_{2} / \mathrm{S}_{3}$ is axial planar to the fold (figure $7 \mathrm{e})$. Commonly the $\mathrm{F}_{2}$ fold axis plunges moderately towards east. However, fold axes show plunge variation in the range of $50^{\circ}-75^{\circ}$ towards $\mathrm{NE}$ to $\mathrm{SE}$ developing a non-cylindricity due to modification by subsequent deformation $\left(\mathrm{D}_{4}\right)$.

Microscopically the porphyroblastic phases in khondalites and leptynitic gneisses do not commonly show retrograde break down textures characteristics of decompression and/or cooling event. However, the high $\mathrm{Mg}-\mathrm{Al}$ rocks in other parts of EGB are susceptible to record any textures during retrograde metamorphic events (Sengupta et al. 1990, 1991; Dasgupta et al. 1994; Bhowmik et al. 1995). $\mathrm{S}_{2}$ gneissic foliation, defined by porphyroblastic phases, developed during near-peak metamorphic condition are subsequently deformed during $\mathrm{D}_{3}$ deformation. Porphyroblastic ferromagnesian phases in the host granulites are sometime replaced by late biotites (figure 3e) as discussed in earlier section. Therefore $\mathrm{D}_{3}$ event may be referred to as post-peak metamorphic deformation.

\section{$5.4 D_{4}$ event}

$\mathrm{D}_{4}$ deformation is characterized by the shear zone development in a compressional regime (transpression). Earlier axial plane of $\mathrm{F}_{2}$ folds has been refolded forming superposed structure, which is the result of interference between $\mathrm{F}_{2}$ and $\mathrm{F}_{3}$. Regional $\mathrm{F}_{3}$ fold axis plunges $55^{\circ}$ towards $54^{\circ}$ with axial trace along $\mathrm{N}-\mathrm{S}$. Systematic variation of $\mathrm{F}_{2}$ fold 
axis occurred due to modification of this fold axis and axial plane due to $\mathrm{D}_{4}$ deformation. The superposed structures are evident in mesoscopic scale. At the southern part of the study area in regional scale modified $\mathrm{F}_{2}$ folds show plunge variations (figure 5) and the axial plane of the regional fold has been curved (figure 6) developing non-plane non-cylindrical fold. Axial trace of this $\mathrm{F}_{3}$ fold strikes broadly along $\mathrm{N}-\mathrm{S}$ direction. Regional scale shear zones are developed in anastomose geometry with sinistral sense (figure 6).
Shear zone runs mainly through granitoids and hence, this is the main rock type, which is affected severely by the development of mylonitic fabric (figure 8a). However, the leptynitic gneiss and charnockite-enderbite gneiss are also affected by the development of high strain zones in outcrop scale. Mylonitic foliations are mostly vertical or steeply dipping $\left(\sim 70^{\circ}\right)$ westerly that intersects the crude foliation of the metagranitoids. The feldspar megacrysts of granitoid gneisses in the shear zone are flattened and elongated forming

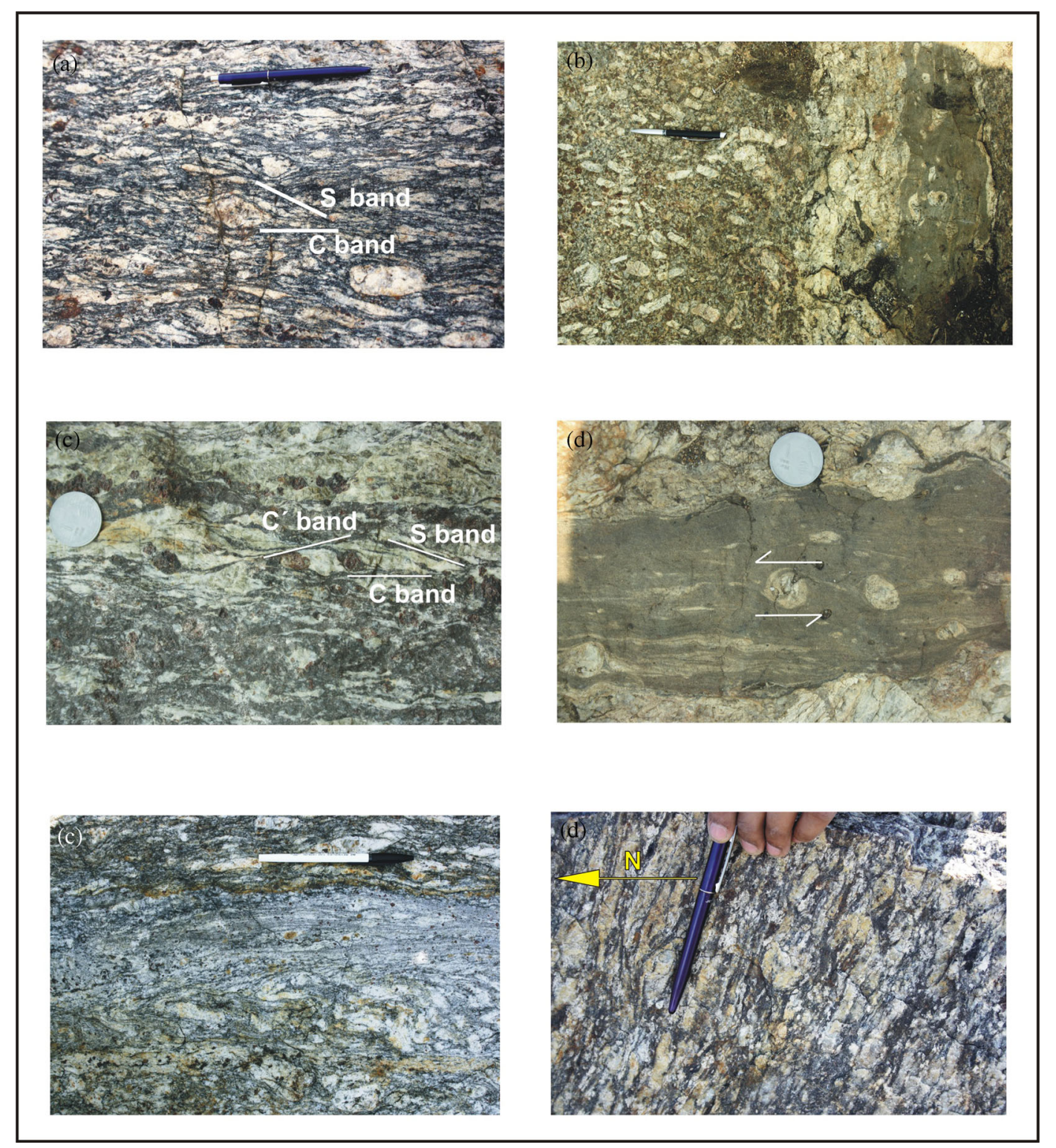

Figure 8. Structural features resulting from the development of shearing in migmatites and granitoid gneisses. (a) Mylonitic fabrics in leuco variety of granitoid gneiss showing $\mathrm{S}-\mathrm{C}$ fabrics marked on it. (b) Ultramylonitic band crosscutting the crude fabric of granitoid gneiss. Note the development of augen-shaped feldspar clasts within fine grained dynamically recrystallized matrix in mylonite band at right part of the figure. (c) $\mathrm{C}-\mathrm{S}-\mathrm{C}$ ' fabrics in mylonitic granitoid gneiss with $\Omega$ plagioclase and garnet clasts. (d) Asymmetirc $\partial$ clast of feldspar in an ultramylonitic shear band in granitoid gneiss suggesting sinistral shear sense. (e) Asymmetric shear folding in the shear bands of migmatitic gneiss. (f) Steeply plunging stretching lineation on subvertical mylonitic foliation in granitoid gneiss. 
augen within the dynamically recrystallized matrix mineral grains producing finer aggregates (figure 8a). The strained feldspar clasts show the pancake shaped or oblate geometry when their axial ratio are plotted in the Flinn diagram (table 2). The values of $\mathrm{X}, \mathrm{Y}$ and $\mathrm{Z}$ are given in table 2, where $\mathrm{Z}$ is the compressive axis, $\mathrm{Y}$ and $\mathrm{X}$ are the extensional axes. The table 2 shows the Flinn $k$ value to be $<1$, which supports the strain parameters in a transpressional shear zone (Dewey et al. 1998; Fossen 2010). Stretching lineations are steep to subvertical in nature on the shear foliation (figure $5)$. Limited number of field data indicate kinematic vorticity number (Wk) to lie in the range of 0 0.81 . Wk is a measure of ratio between pure shear and simple shear. Wk is measured with the angle between $\mathrm{C}$ fabric and $\mathrm{S}$ fabric $(\varnothing)$ on the horizontal plane and the $\mathrm{X}-\mathrm{Z}$ parameters of feldspar clasts in the granitoids following $\mathrm{R}_{\mathrm{f}}-\varnothing$ method (Twiss and Moores 2007; Bo et al. 2009). The dynamically recrystallized ultramylonitic bands crosscut earlier gneissic fabric in granitoid gneisses (figure 8b). Depending on clasts/refined matrix ratio protomylonite, mylonite, and ultramylonite can be assigned (Ghosh 1993) for the sheared rocks. All the varieties are preserved in the area. Several shear sense indicators like $\mathrm{S}-\mathrm{C}$ fabric, asymmetric shear fold, $\partial$ and $\Omega$ structures have proved useful. S-C, C-S-C', C-C' fabrics (figure 8c) are characteristic in the sheared granitoid gneisses, which suggest the sinistral sense of shearing. Both the $\partial$ - and $\Omega$ shaped feldspar clasts are preserved in the sheared granitoids (figure 8d). Asymmetric shear related folds are also a distinguishing feature in the shear zone (figure 8e) migmatites and as 'similar folds' in the granitoids (Ramsay 1967; Valentin 2000). All the structures of the shear zone suggest overall sinistral shear sense. Stretching lineation on the subvertical mylonitic foliation plunges moderate to steep (figure 8f) implying a dip-slip component in addition to the significant strike-slip component of shearing. Conjugate shears are also noticed where subvertical main shear zone strikes $45^{\circ}$ with minor shear band trending $\mathrm{E}-\mathrm{W}$.

Table 2. Axial parameters and calculation of corresponding Flinn $k$ values of feldspar clasts in sheared granitoids. $Z$ is the compressional axis whereas $X$ and $Y$ are the extensional axes. The parameters plotted in the Flinn diagram are shown here.

\begin{tabular}{|c|c|c|c|c|c|c|c|c|}
\hline Data no. & $\mathrm{X}$ & $\mathrm{Y}$ & $\mathrm{Z}$ & $\mathrm{X} / \mathrm{Y}$ & $\mathrm{Y} / \mathrm{Z}$ & $\ln (\mathrm{X} / \mathrm{Y})$ & $\ln (\mathrm{Y} / \mathrm{Z})$ & $k$ value \\
\hline 1 & 5.7 & 5 & 1 & 1.140 & 5.000 & 0.131 & 1.609 & 0.035 \\
\hline 2 & 5 & 5 & 1.7 & 1.000 & 2.941 & 0.000 & 1.079 & 0.000 \\
\hline 3 & 6 & 6 & 2.1 & 1.000 & 2.857 & 0.000 & 1.050 & 0.000 \\
\hline 4 & 8 & 7 & 2.5 & 1.143 & 2.800 & 0.134 & 1.030 & 0.079 \\
\hline 5 & 6 & 6 & 2 & 1.000 & 3.000 & 0.000 & 1.099 & 0.000 \\
\hline 6 & 4.7 & 3.3 & 1 & 1.424 & 3.300 & 0.354 & 1.194 & 0.184 \\
\hline 7 & 6 & 6 & 2.1 & 1.000 & 2.857 & 0.000 & 1.050 & 0.000 \\
\hline 8 & 8 & 7 & 2.5 & 1.143 & 2.800 & 0.134 & 1.030 & 0.079 \\
\hline 9 & 6 & 3.8 & 1 & 1.579 & 3.800 & 0.457 & 1.335 & 0.207 \\
\hline 10 & 7 & 3 & 1 & 2.333 & 3.000 & 0.847 & 1.099 & 0.667 \\
\hline 11 & 4.5 & 4.5 & 1.6 & 1.000 & 2.813 & 0.000 & 1.034 & 0.000 \\
\hline 12 & 6.9 & 6.5 & 1.5 & 1.062 & 4.333 & 0.060 & 1.466 & 0.018 \\
\hline 13 & 6.7 & 4 & 1.2 & 1.675 & 3.333 & 0.516 & 1.204 & 0.289 \\
\hline 14 & 7 & 5 & 1.5 & 1.400 & 3.333 & 0.336 & 1.204 & 0.171 \\
\hline 15 & 8 & 7 & 2.5 & 1.143 & 2.800 & 0.134 & 1.030 & 0.079 \\
\hline 16 & 4 & 3.5 & 1.1 & 1.143 & 3.182 & 0.134 & 1.157 & 0.065 \\
\hline 17 & 5.3 & 4.5 & 1.2 & 1.178 & 3.750 & 0.164 & 1.322 & 0.065 \\
\hline 18 & 6.9 & 6.5 & 2 & 1.062 & 3.250 & 0.060 & 1.179 & 0.027 \\
\hline 19 & 6.7 & 5.7 & 1.8 & 1.175 & 3.167 & 0.162 & 1.153 & 0.081 \\
\hline 20 & 8 & 6.9 & 2 & 1.159 & 3.450 & 0.148 & 1.238 & 0.065 \\
\hline
\end{tabular}

$\mathrm{k}=\propto$

Flinn diagram :

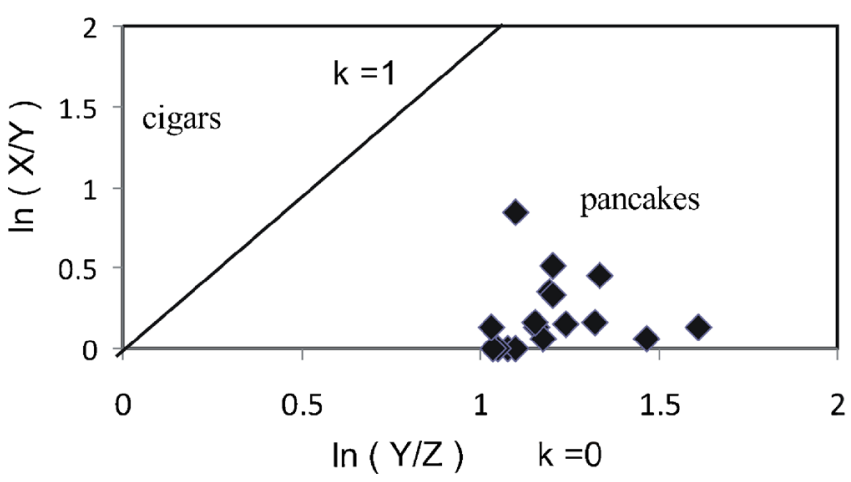


In outcrop scale, $\mathrm{F}_{3}$ folds are developed on $\mathrm{S}_{2}$ fabric in $\mathrm{D}_{4}$ deformation. Both $\mathrm{F}_{2}$ and $\mathrm{F}_{3}$ folds are developed on same form surface $\mathrm{S}_{2}$. Interference of $\mathrm{F}_{2}$ and $\mathrm{F}_{3}$ folds produces superposed fold structures. $\mathrm{F}_{3}$ fold axes plunge $50^{\circ}-80^{\circ}$ towards $\mathrm{N}$ to NE. Variations of plunge suggest the modification of $F_{2}$ to $F_{3}$. Near Ullibhadra, axial plane of $F_{2}$ fold has been curved forming non-plane cylindrical fold (figure 7c). Near Gadabavalasa, $\mathrm{F}_{2}$ fold on $\mathrm{S}_{2}$ foliation has been modified with the development of $\mathrm{F}_{3} . \mathrm{F}_{2}$ fold on mafic band in the gneissic rock has also been refolded in this deformation.

Granitoids are classified based on intensity of development of mylonitic foliation and flattening of

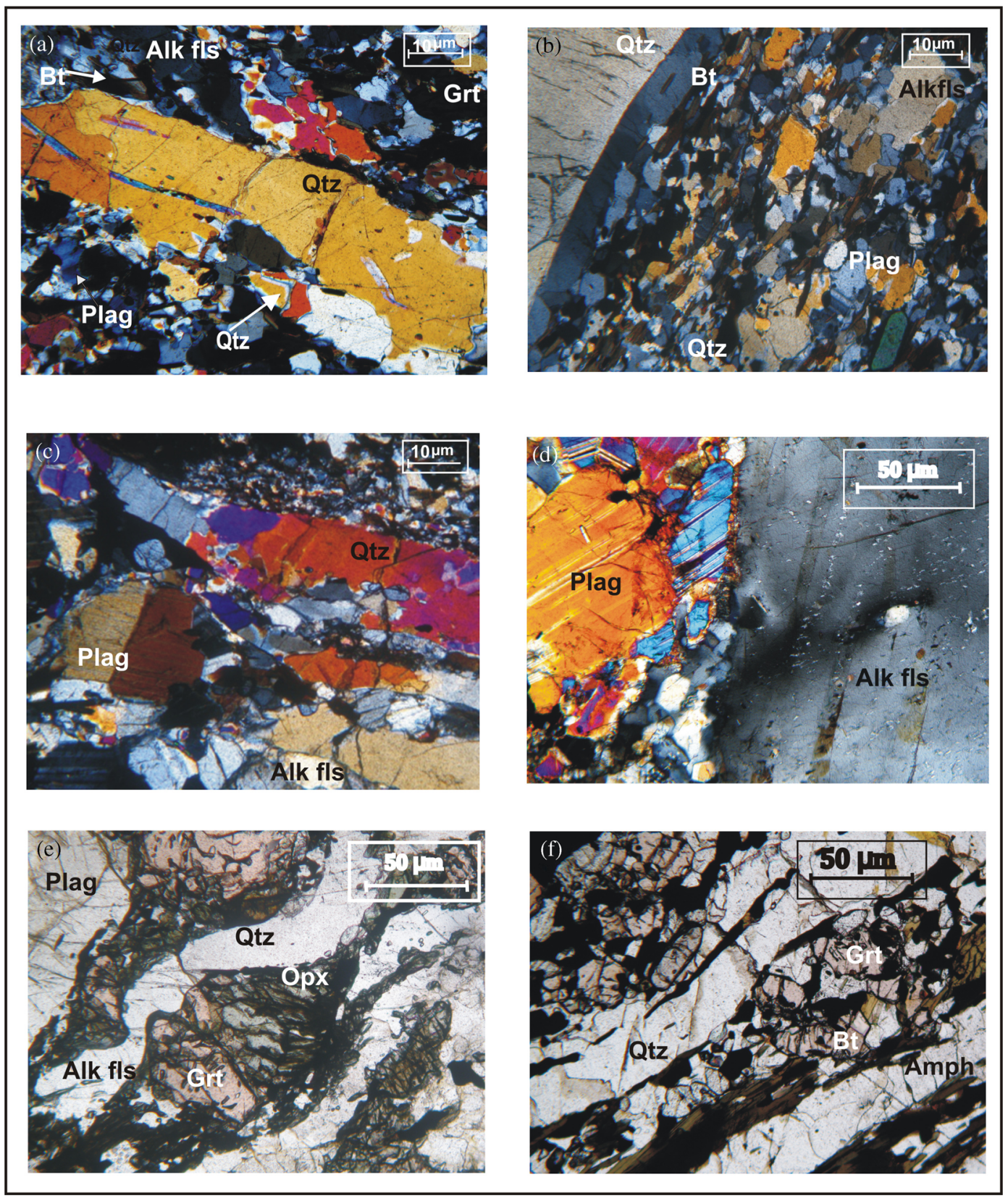

Figure 9. Microstructural features in sheared granitoid gneisses. (a) Polycrystalline quartz (Qtz) ribbon in a matrix composed of dynamically recrystallized alkali feldspar (Alk fls), plagioclase (Plag), biotite (Bt) and garnet (Gt). (b) Deformed fabric forming quartzofeldpathic matrix minerals like quartz (Qtz), plagioclase (Plag) and alkali feldspar (Alk fls) grains with serrated grain boundaries with biotite flakes indicating subgrain rotation in a mylonitic granitoid gneiss. (c) Flattened and recrystallized quartz (Qtz) grains with subgrain formation and developing ribbons. (d) Plagioclase (Plag) and alkali feldspar (Alk fls) clasts showing deformation twinning and subgrain formation at the grain boundary in a less sheared granitoid gneiss. (e) Garnet (Grt) and orthopyroxene (Opx) porphyroblast wrapped up by quartz (Qtz) ribbon in a deformed matrix containing alkali feldspar (Alk fls), plagioclase (Plag) and quartz (Qtz). (f) Fractured Garnet (Grt) porphyroblast containing biotite (Bt) and quartz (Qtz) inclusions are replaced by late biotite (Bt). Note the presence of amphibole (Amph) in the matrix. 
clasts and matrix minerals and grain refinement as unsheared, less-sheared, and highly-sheared varieties (Platt and Behr 2011; Passchier and Trouw 2005; Hippertt et al. 2001). The unsheared, lesssheared, and highly-sheared varieties are spatially distributed in the terrane when approaching towards regional scale or outcrop scale shear zones. Different stages of crystal-plastic deformation are preserved in sheared granitoids, which are the main mechanisms for grain refinement processes and mylonitic fabric development. Sheared granitoids are sometimes characterized by alternating leucosomal and melanosomal fractions. The leucosomal fraction is composed of large inequigranular interlobate texture composed of alkali feldspar, and plagioclase feldspar clasts (figure 9a) in a matrix of dynamically recrystallized quartz, alkali feldspar, and plagioclase relict. Plagioclase feldspar clasts develop augen texture with relatively undeformed core and surrounding recrystallized grains at the rim to sigma type mantled objects with deformed core. Monocrystalline quartz ribbon of aspect ratio $>7: 1$ is observed. These grains show sweeping extinction. However, polycrystalline quartz ribbons with L/W >10:1 with development of subgrains (figure 9a) are also noticed. The ribbons occur along the shear foliation. Most feldspar grains in the matrix show typical subgrain rotation (SGR) associated to climb (figure 9b). Ultramylonitized bands are composed of quartz, alkali feldspar, and plagioclase in decreasing order of abundance. Quartz grains suffer crystal plastic deformation as indicated by the undulose extinction and subgrain formation (figure 9c). Feldspar grains in relatively undeformed rock contain deformation twin and BLG dominated grain boundary migration (GBM) process associated with subgrain formation (figure 9d). Inequigranular interlobate plagioclase grains with $\mathrm{L} / \mathrm{W} \leq 5: 1$ form subgrains and deformation twinning. Alkali feldspar grains form ribbon-like texture with $\mathrm{L} / \mathrm{W}$ ratio of $4: 1-5: 1$. Hydrous minerals like biotite and amphiboles are developed and oriented along the shear bands. Garnet, orthopyroxene, biotite, and amphibole grains are stretched along the shear foliation (figure 9e). Orthopyroxene grains are stretched along the shear foliation showing weak undulose extinction and deformation lamellae. They are bordered by finely recrystallized quartzofeldspathic matrix with serrated plagioclase grains having deformed twin lamellae. Amphiboles are recrystallized along grain boundary with deformed rotated lamellae. Porphyroblastic garnets are rimmed by feldspar and quartz intergrowth. The former grains occur within the quartzofeldspathic melt fraction exhibit fractures and BLG with the feldspathic melt. Well-developed fractures in garnet grains are filled up by biotite and opaque phases (figure 9f).

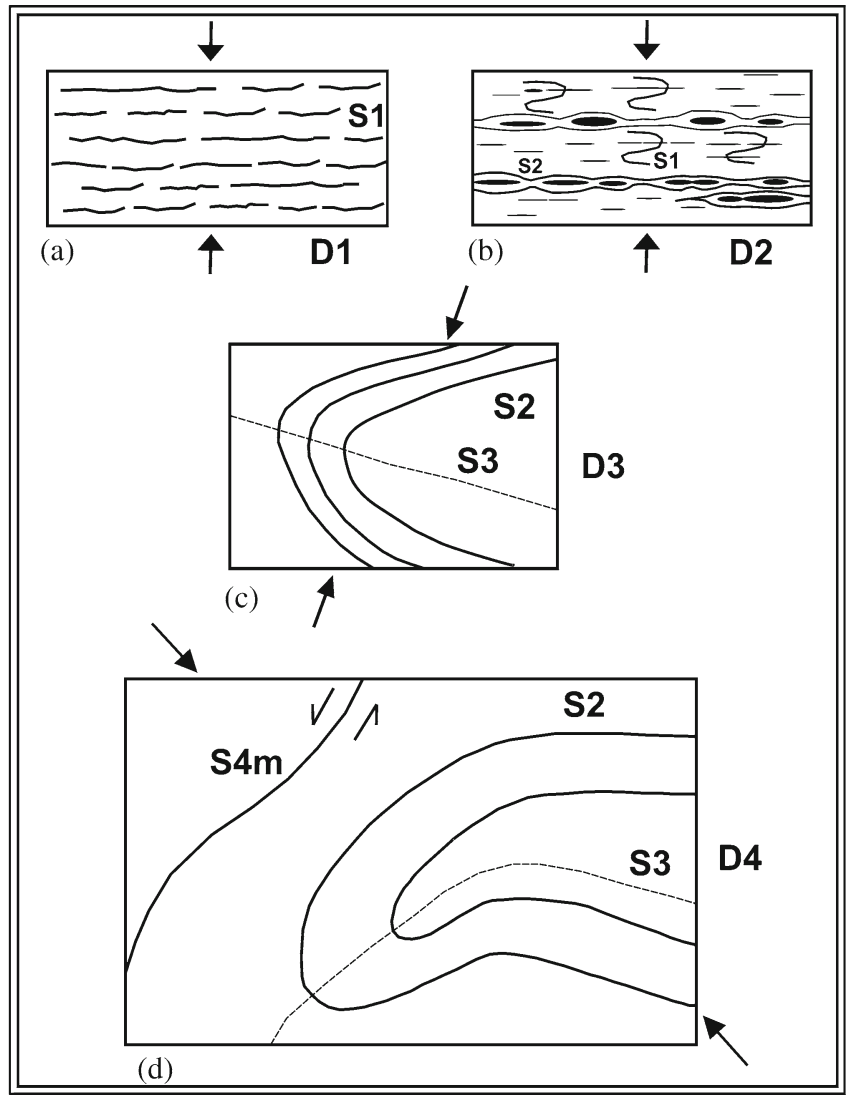

Figure 10. Schematic diagram showing the chronological development of the structural fabrics throughout the deformation events. (a) Development of $\mathrm{S}_{1}$ fabric $\mathrm{D}_{1}$ event during prograde metamorphic condition. (b) Development of $\mathrm{S}_{2}$ gneissic fabric with porphyroblasts which is axial planar to the rootless folds $\left(\mathrm{F}_{1}\right)$ on by $\mathrm{S}_{1}$ during deformation event $\mathrm{D}_{2}$ during peak metamorphic condition. (c) Post-peak $\mathrm{D}_{3}$ event causing deformation and folding $\left(\mathrm{F}_{2}\right)$ of $\mathrm{S}_{2}$ gneissic fabric and development of $\mathrm{S}_{3}$ fabric axial planar to the $\mathrm{F}_{2}$ folds in local scale. (d) Development of sinistral shear zones and superposed non-plane non-cylindrical folding resulting from a bulk compression at an angle to the shearing in $\mathrm{D}_{4}$ event.

The grain boundaries show bulging and are serrated in nature suggesting relatively high-T GBM mechanism and generate interlobate inequigranular texture. Smaller garnets show L/W ratio of 4:1-3:1 in mylonitic shear bands. Quartz ribbons and recystallized quartzofeldspathic matrix grains wrap around the porphyroblastic garnets (figure 9e).

\section{Discussion}

The polydeformed polymetamorphed Domain 2 (Visakhapatnam Domain) of EGB suffered anticlockwise metamorphic P-T trajectory (Sengupta et al. 1990, 1991; Dasgupta et al. 1994; Karmakar et al. 2009 and references therein). Our detailed structural study suggests four distinct petrotectonic events (figure 10). $\mathrm{D}_{1}$ event refering to 


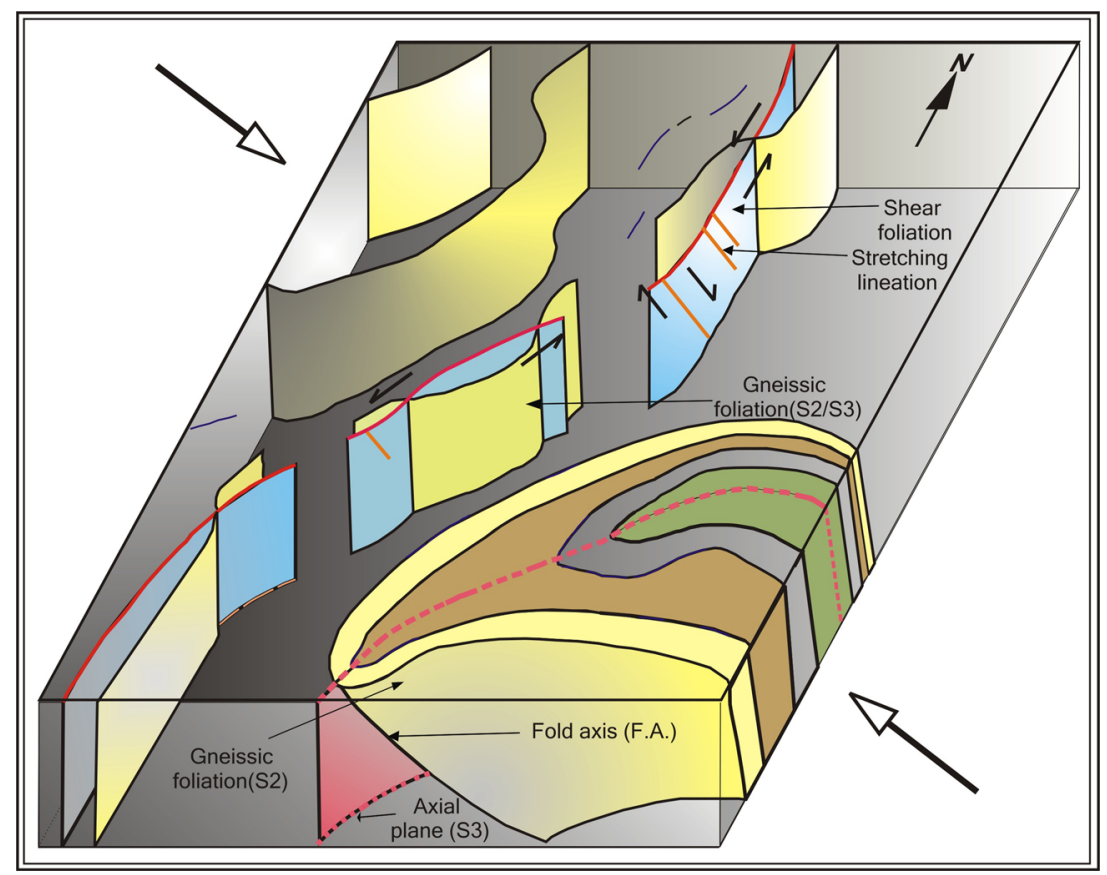

Figure 11. Schematic three dimensional block diagram showing present structural disposition of the area after $\mathrm{D}_{4}$ event. Shear sense is marked on the shear foliation both on horizontal outcrop section and on vertical foliation along stretching lineation with a compressive force broadly along northwest-southeast direction. Western part is up-thrown block relative to the eastern part.

the prograde $\mathrm{M}_{1}$ history of metamorphism and transformation mechanism from primary layering to $\mathrm{S}_{1}$ is now obliterated. The event is possibly the initiation of high-grade metamorphism as evident from development of thinly laminated quartzofeldspathic units in migmatitic gneiss (figure 7a) resulting incipient partial melting (described in section 5.1). However, detailed characterization and the timing of prograde event in other parts of Domain 2 still remain inconclusive (Sengupta et al. 1990; Dasgupta et al. 1994; Das et al. 2011). The granitoids got emplaced during pre-peak to peak metamorphic condition, i.e., pre- to syn- $\mathrm{D}_{2}$ event.

The granitoids are monzogranitic to granodioritic type based on normative classification and are of subalkaline nature (Middlemost et al. 1994). The metaluminous to peraluminous character (figure 4d) and I- and S-type nature of granitoids indicate a continental arc to collisional set up of emplacement probably related to active continental margin (Barbarin 1999). Two different mineralogical assemblages for grey and leuco granitoids (described earlier in section 2) with weak dissimilar trends in calcic to calc alkaline nature (figure 4d) in granitoids suggest evolution of two suites of rocks.

Development of $\mathrm{S}_{2}$ gneissic foliation defined by porphyroblatic garnets in granitoid gneisses is conformable with the pervasive regional gneissic foliation $\left(\mathrm{S}_{2}\right)$ in the associated migmatitic gneisses and khondalites. $\mathrm{D}_{2}$ event is therefore referred to as porphyroblastic garnet forming peak metamorphic granulite grade $\mathrm{M}_{2}$ event. The peak granulite event is characterised from $\mathrm{Mg}-\mathrm{Al}$ rocks and other granulites in other parts of EGB (Sengupta et al. 1990, 1991; Karmakar and Fukuoka 1992; 1998; Bose et al. 2000, 2009; Das et al. 2011, 2012, 2013; Dasgupta et al. 1994). The granitoid gneisses bear the signatures of peak porphyroblasts development event with partial melting. $\mathrm{D}_{3}$ event deforms this $\mathrm{S}_{2}$ gneissic foliation at post-peak metamorphic condition and exhibits outcrop to regional scale $\mathrm{F}_{2}$ folding. The D4 event is characterized by (i) presence of superposed fold structure; (ii) development of vertical to near vertical mylonitic foliation in regional and outcrop scale; (iii) steeply plunging stretching lineation; (iv) value of Flinn $k$ ranging between zero and 1 ; and (v) kinematic vorticity number $(\mathrm{Wk})<0.81$. It can be ascertained from the above evidences that the shear zone in our study area is mostly of pure shear dominated transpressional regime (Fossen et al. 1994). So, $\mathrm{D}_{4}$ is characterized by transpression with bulk shortening broadly along NW-SE direction (figure 10d). The resultant structure is illustrated using a schematic three dimensional block diagram (figure 11). In transpression the convergence vector is not orthogonal relative to the deformation zones in tectonic scale (Fossen et al. 1994; Dewey et al. 1998; Goscombe et al. 2003). The event is indicated by the development of anastomosing shear zones with superposed fold structures. Transpressional tectonics is instrumental in understanding the relative motion of crustal sections studied from different parts of the world (Ave Lallement 1997; Goscombe 
et al. 2003) and is said to be an inevitable result of plate motion on a spherical surface (Dewey et al. 1998). Coupled interference of pure shear and simple shear stresses generates this situation in crustal rocks in compressional regime (Fossen et al. 1994; Fossen 2010). Pure shear acts to generate shortening normal to the shear zone and the asymmetricity in rocks and minerals are related to simple shear deformation. The transpressive zones always show noncoaxial strain pattern. In our area, structural studies imply sinistral motion of shearing with eastern part moved downward relative to the western part as upthrown block as suggested by shear sense indicators and stretching lineation (figure 11). Regional scale shear zones are confined within granitoids and leptynitic gneisses. However, other rocks including massive charnockites register development of micro shear bands with influence of regional high-strain zones. The coarse-grained quartzofeldspathic rocks like megacrystic granitoids and leptynites were probably rheologically susceptible to accommodate highstrain zones. Hydrous minerals like biotite and amphiboles are developed along the shear bands. However, large-scale melting and decompression textures are not apparent suggesting this reworking event takes place possibly without significant upliftment.

Mukhopadhyay and Bhattacharya (1997) illustrated the emplacement of granitoid syntectonically during prograde to peak metamorphic condition whereas the shearing is suggested as post-peak event. On the contrary, Chetty et al. (2003) inferred the granitoid emplacement at a much later event during development of shear zones. Chetty (2001) interpreted the EGB as collage of juxtaposed terranes (?) demarcated by the lineaments based on Landsat imagery data and suggested to fit a thrust tectonic, allochthonous model of amalgamation and accretion. Dasgupta et al. (2013) argued that the central EGB witnessed a prolonged accretion-collision history initiated at $1.5 \mathrm{Ga}$ and culminated at ca $0.90 \mathrm{Ga}$ with the formation of supercontinent Rodinia. The Domain 2 is bounded by the NSZ-VSZ lineament at northeast with Domain 3 and by Sileru shear zone (SSZ) at east with Domain 1B. However, present study area falls within the Nagavalli shear zone (NSZ) and our study reveals that the shear zones pass through granitoid gneisses. Sharp intrusive nature of granitoids apparent from the field relation clearly suggests that the megacrystic granitoids and charnockites intruded the package of rocks comprising migmatitic gneisses, charnockiteenderbites, quartzites, and khondalites. The host granulites are metamorphosed and deformed in the same manner as reflected from their petrological and structural studies described earlier. Chetty et al. (2003) suggested thrust tectonics from development of flat to moderately dipping $\mathrm{D}_{1}$ gneissic foliation (prior to the development of shear zones) from the present study area and correlated it with Archaean tectonothermal event based on $\mathrm{Sm}-\mathrm{Nd}$ and $\mathrm{Rb}-\mathrm{Sr}$ data from Domain 4 by Bhattacharyya et al. (2004). However, Simmat and Raith (2008) bracket early ultra-high temperature metamorphism within 1250-1100 Ma $\left(\mathrm{M}_{1}\right)$ using monazite chemical age data in khondalites and aluminous granulites and fabric defining granulites facies metamorphism $\left(\mathrm{M}_{2}\right)$ and anatexis in metapelites and felsic granulites between 980 and $940 \mathrm{Ma}$, synchronous with the intrusion of megacrystaic granitoids in EGP. In a recent study, UHT metamorphism in Domain 2 is demonstrated as occuring during 1.03-0.99 Ga using U-Pb zircon SHRIMP data (Bose et al. 2011; Das et al. 2011). The present study suggests that $D_{2}$ is the major pervasive fabric $\left(\mathrm{S}_{2}\right.$ gneissic foliation) forming event and reflects the peak metamorphic condition $\left(\mathrm{M}_{2}\right)$. However, systematic geochronological study is required to correlate this peak metamorphic event of the area with the recorded $\mathrm{M}_{2}$ event of EGB. Chetty et al. (2003) speculated that the $\mathrm{D}_{2}$ deformation corresponds to the development of a network of steep shear zones such as Sileru Shear Zone (SSZ), Nagavalli Shear Zone (NSZ), and Vamsadhara Shear Zone (VSZ). Over a period of 1450-850 Ma, granitoids got emplaced syntectonically with this $\mathrm{D}_{2}$ deformation. However, it needs to be substantiated by the systematic geochronological data. They inferred NSZ-VSZ joins up with Rayner-Napier boundary shear zone in Antarctica. Present petrotectonic studies (shear zone forming $\mathrm{D}_{4}$ event) indicate the mylonitic foliation overprinted the $\mathrm{S}_{2}$ gneissic foliation of granitoids that emplaced before this event at pre- to peak metamorphic condition. This, in combination with already discussed isotopic investigations, in contrast suggests that the development of shearing may be younger than 1.03-0.99 Ga. It is reported by Chetty et al. (2003) to show the dextral shear sense. However, Mukhopadhyay and Basak (2009) argued that dextral motion is not kinematically compatible with regional framework of EGB. Our detailed structural studies invoke sinistral motion of shearing with eastern part as downthrown block relative to the western part as upthrown block. From the sequential development of transposed planar fabrics and superposed fold structures revealed from regional, outcrop and microstructural studies in four distinct events $\left(D_{1}-D_{4}\right)$, we suggest that the granitoids emplaced at pre- to syn-peak metamorphic condition (preto syn- $\mathrm{D}_{2}$ event) in the terrane and experienced compressional tectonics with transpression at $\mathrm{D}_{4}$ due to oblique collision directed broadly towards 
NNW manifested by development of sinistral shear zones.

\section{Acknowledgements}

TS acknowledges CSIR, for Junior and Senior Research Fellowship (File No. 09/096(0652)/2010EMR-I) and SK acknowledges CAS and UPE II, Dept. of Geological Sciences, Jadavpur University. The authors acknowledge Subhabrata Bera for his assistance during fieldwork. They also acknowledge Pulak Sengupta for the editorial work. Constructive and thorough reviews of Sankar Bose and an anonymous reviewer helped to improve the quality of the paper.

\section{References}

Ave Lallement H G 1997 Transpression, displacement partitioning, and exhumation in the eastern Caribbean/South American plate boundary zone; Tectonics 16 272-289.

Barbarin B 1999 A review of the relationships between granitoid types, their origins and their geodynamic environments; Lithos 46 605-626.

Bhadra S, Gupta S and Banerjee M 2004 Structural evolution across the Eastern Ghats Mobile Belt-Bastar Craton boundary, India: Hot over cold thrusting in an ancient collision zone; J. Struct. Geol. 26 233-245.

Bhattacharyya S, Swain A K and Teixeira W 2004 Crustal source for a syenite complex in the high-grade Eastern Ghats belt, India: Sm-Nd isotopic evidence; Gondwana Res. 7 627-629.

Bhowmik S K, Dasgupta S, Hoerness S and Bhattacharya P K 1995 Extremely high temperature calcareous granulites from the Eastern Ghats, India: Evidence for isobaric cooling, fluid buffering and terminal channelized fluid flow; Eur. J. Mineral. 7 689-703.

Biswal T K, De Waele B and Ahuja H 2007 Timing and dynamics of the juxtaposition of the Eastern Ghats Mobile Belt against the Bhandara Craton: A structural and zircon U-Pb SHRIMP study of the fold-thrust belt and associated nepheline syenite plutons; Tectonics $\mathbf{2 6}$ $1-21$.

Biswal T K and Sahoo D 1998 IRS-1C Digital data interpretation of lithotectonic setting in northwestern part of the Eastern Ghats Mobile Belt, Orissa; Curr. Sci. 75 846-850.

Bo Z, JinJiang Z, DaLai Z and Lei G 2009 Strain and kinematic vorticity analysis: An indicator for sinistral transpressional strain partitioning along the Lancanjiang shear zone, western Yunnan, China; Science in China Series D: Earth Sci. 52 602-618.

Bose S, Das K, Ohnishi I, Torimoto J, Karmakar S, Shinoda K and Dasgupta S 2009 Characterization of oxide assemblages of a suite of granulites from Eastern Ghats Belt, India: Implication to the evolution of $\mathrm{C}-\mathrm{O}-\mathrm{H}-\mathrm{F}$ fluids during retrogression; Lithos 113 483-497.

Bose S, Dunkley D J, Dasgupta S, Das K and Arima M 2011 India-Antarctica-Australia-Laurentia connection in the Paleo-Mesoproterozoic revisited: Evidence from new zircon $\mathrm{U}-\mathrm{Pb}$ and monazite chemical age data from the Eastern Ghats Belt, India; Geol. Soc. Am. Bull. 123 2031-2049.

Bose S, Fukuoka M, Sengupta P and Dasgupta S 2000 Evolution of high $\mathrm{Mg}-\mathrm{Al}$ granulites from Sunkarametta, Eastern Ghats, India: Evidence for a lower crustal heating-cooling trajectory; J. Metamorph. Geol. 18 223-240.

Butler R W H and Freeman S 1996 Can crustal extension can be distinguished from thrusting in the internal parts of mountain belts? A case history of the Entrelor shear zone, Western Alps; J. Struct. Geol. 18 909-923.

Cawood P A, Kröner A, Collins W J, Kusky T M, Mooney W D and Windley B F 2009 Accretionary orogens through Earth history; Geol. Soc. London Spec. Publ. 318 $1-36$.

Chetty T R K 2001 The Eastern Ghats Mobile Belt, India: A collage of juxtaposed terranes (?); Gondwana Res. 4 319-328.

Chetty T R K, Vijaya P, Narayana B L and Giridhar G V 2003 Structure of the Nagavalli shear zone, Eastern Ghats Mobile Belt, India. Correlation in the East Gondowana reconstruction; Gondwana Res. 6 215-229.

Das K, Bose S, Karmakar S and Chakraborty S 2012 Petrotectonic framework of granulites from northern part of Chilka Lake area, Eastern Ghats Belt, India: Compressional vis-à-vis transpresional tectonics; J. Earth Syst. Sci. 121 1-17.

Das K, Bose S, Karmakar S, Dunkley D J and Dasgupta S 2011 Multiple tectonometamorphic imprints in the lower crust. First evidence of ca $950 \mathrm{Ma}$ (zircon U-Pb SHRIMP) compressional reworking of UHT aluminous granulites from the Eastern Ghats Belt, India; Geol. J. $46217-239$.

Das K, Naotaka T, Bose S and Ando J 2013 On oriented ilmenite needles in garnet porphyroblasts from deep crustal granulites: Implications for fluid evolution and cooling history; Lithos 156-159 230-240.

Das S, Nasipuri P, Bhattacharya A and Swaminathan S 2008 The thrust-related contact between the Eastern Ghats Belt and the adjoining Bastar Craton (Eastern India): Evidence from mafic granulites and tectonic implications; Precamb. Res. 162 70-85.

Dasgupta S, Bose S and Das K 2013 Tectonic evolution of the Eastern Ghats Belt, India; Precamb. Res. 227 247-258.

Dasgupta S, Sanyal S, Sengupta P and Fukuoka M 1994 Petrology of granulites from Anakapalle - evidence for Proterozoic decompression in the Eastern Ghats, India; J. Petrol. 35 433-459.

Dasgupta S and Sengupta P 2003 Indo-Antarctic correlation: A perspective from the Eastern Ghats Belt; In: Proterozoic East Gondowana: Supercontinent assembly and breakup (eds) Yoshida M, Windley B F and Dasgupta S, Geol. Soc. London Spec. Publ. 206 131-143.

Dewey J F, Holdsworth R E and Strachan R A 1998 Transpression and transtension zones; In: Continental transpressional and transtensional tectonics (Eds) Dewey J F, Holdsworth R E and Strachan R A; Geol. Soc. London Spec. Publ. 135 1-14.

Dobmeier C 2006 Emplacement of proterozoic massif-type anorthosite during regional shortening: Evidence from the Bolangir anorthosite complex (Eastern Ghats Province, India); Int. J. Earth Sci. 95 543-555.

Dobmeier C J and Raith M M 2003 Crustal architecture and evolution of the Eastern Ghats Belt and adjacent regions of India; In: Proterozoic East Gondowana: Supercontinent Assembly and Breakup (eds) Yoshida M, Windley B F and Dasgupta S, Geol. Soc. London Spec. Publ. 206 $145-168$.

Dobmeier C and Simmat R 2002 Post Grenvillian transpression in the Chilka Lake area, Eastern Ghats Belt - implications for the geological evolution of peninsular India; Precamb. Res. 113 243-268.

Fossen H 2010 Structural Geology (First edn); Cambridge University Press. 
Fossen H, Tikoff B and Teyssier C 1994 Strain modelling of transpressional and transtensional deformation; Nor. Geol. Tidsskr. 74 134-145.

Frost B R, Barnes C G, Collins W J, Arculus R J, Ellis D J and Frost C D 2001 A geochemical classification for granitic rocks; J. Petrol. 42 2033-2048.

Middlemost E A K Naming materials in the magma/igneous rock system; Earth Sci. Rev. 37 215-224.

Ghosh S K 1993 Structural Geology - Fundamentals and Modern Developments; Pergamon Press Ltd.

Goscombe B D, Hand M, Gray D and Mawby J 2003 The metamorphic architecture of a transpressional orogen: The Kaoko Belt, Namibia; J. Petrol. 44 676-711.

Gupta S 2012 Strain localization, granulite formation and geodynamic setting of 'hot orogens': A case study from the eastern Ghats Province, India; Geol. J. 47 334-351.

Gupta S, Nanda J, Mukherjee S K and Santra M 2005 Alkaline magmatism versus collisional tectonics in the Eastern Ghats Belt, India; Gondwana Res. 8 403-419.

Hippertt J, Rocha A, Lana C, Egydio-Silva $\mathrm{M}$ and Takeshita T 2001 Quartz plastic segregation and ribbon development in high grade striped gneiss; J. Struct. Geol. 23 67-80.

Karmakar S, Bose S, Das K and Dasgupta S 2009 Proterozoic Eastern Ghats Belt, India - A witness of multiple orogenies and its lineages with ancient supercontinents; J. Vir. Explorer 32 paper 3.

Karmakar S and Fukuoka M 1998 Successive metamorphism from a suite of granulite facies rocks from Araku Valley; Implications for the $\mathrm{P}-\mathrm{T}$ trajectory in the Eastern Ghats; Geol. Soc. London Spec. Publ. 44 201-219.

Karmakar S and Fukuoka M 1992 Genesis of leptynites: Evidence from Araku Valley, Eastern Ghats, India; Indian Minerals 46 247-258.

Kovach V P, Narayana B L, Rao A T, Yoshida M, Rao P R, Rao V D, Kotov A B and Salkinova E B 1997 Sm-Nd isotopic investigations in the central part of the Estern Ghats Granulite Belt; Int. Field workshop on Proterozoic Geology of Madagascar; Gondwana Res. Group Misc. Publ. 5(Abs) 40.

Middlemost E A K 1994 Naming materials in the magma/ igneous rock system; Earth Sci. Rev. 37 215-224.

Moresi L, Betts P G, Miller M S and Cayley R A 2014 Dynamics of continental accretion; Nature $\mathbf{5 0 8}$ 245-248.

Mukhopadhyay A K and Bhattacharya A 1997 Tectonothermal evolution of the gneiss complex at Salur in the Eastern Ghats Granulite Belt of India; J. Metamorph. Geol. 15 719-734.
Mukhopadhyay D and Basak K 2009 The Eastern Ghats Belt - A polycyclic granulite terrain; J. Geol. Soc. India 73 489-518.

Narayana B L, Rama Rao P, Reddy G L N and Divakara Rao V 1999 Geochemistry and origin of megacrystic granitoid rocks from Eastern Ghats Granulite Belt; Gondwana Res. 2 105-115.

O'oconnor J T 1965 A classification for quartz-rich igneous rocks based on feldspar ratios; In: US Geol. Surv. Prof. Paper B525 USGS 79-84.

Passchier C W and Trouw A J T 2005 Microtectonics; Springer, Berlin-Heidelberg-New York.

Platt J P and Behr W M 2011 Grainsize evolution in ductile shear zones: Implications for strain localization and strength of the lithosphere; J. Struct. Geol. 33 537-550.

Plujim B A van der, Mezger K, Cosca M A and Essene E J 1994 Determining the significance of high-grade shear zones by using temperature-time paths, with examples from the Grenvillian orogen; Geology 22 743-746.

Ramsay J G 1967 Folding and fracturing of rocks; McGraw Hill.

Ramakrishnan M, Nanda J K and Augustine P F 1998 Geological evolution of the Proterozoic Eastern Ghats Mobile Belt; Geol. Surv. India Spec. Publ 44 1-21.

Rickers K, Mezger K and Raith M M 2001 Evolution of the continental crust in the Proterozoic Eastern Ghats Belt, India and new constraints for Rodinia reconstruction: Implications from $\mathrm{Sm}-\mathrm{Nd}, \mathrm{Rb}-\mathrm{Sr}$ and $\mathrm{Pb}-\mathrm{Pb}$ isotopes; Precamb. Res. 112 183-210.

Sengupta P, Dasgupta S, Bhattacharya P K, Fukuoka M, Chakraborti S and Bhowmick S 1990 Petrotectonic imprints in the Sapphirine granulites from Anantagiri, Eastern Ghats Mobile Belt, India; J. Petrol. 31 971-976.

Sengupta P, Karmakar S, Dasgupta S and Fukuoka M 1991 Petrology of spinel granulites from Araku, Eastern Ghats, India, and a petrogenetic grid for Sapphirine free rocks in the system FMAS; J. Metamorph. Geol. 9 451-459.

Simmat R and Raith M M 2008 U-Th- $\mathrm{Pb}$ monazite geochronometry of the Eastern Ghats Belt, India: Timing and spatial disposition of poly metamorphism; Precamb. Res. 162 16-39.

Streckeisen A 1974 Classification and nomenclature of plutonic rocks; Geol. Rundsch 63 773-786.

Twiss T J and Moores E M 2007 Structural Geology, 2nd edn, W.H. Freeman and Company.

Valentin Ez 2000 When shearing is a cause of folding; Earth Sci. Rev. 51 155-172.

Whalen J B, Currie K L and Chappell B W 1987 A type granites: Geochemical characteristics, discrimination and petrogenesis; Contrib. Mineral. Petrol. 95 407-419. 